\title{
Monitoring a newly re-born patient: water quality and cyanotoxin occurrence in a reconstructed shallow Mediterranean lake
}

\author{
Spyros Gkelis, ${ }^{1 *}$ Manthos Panou, ${ }^{1}$ Ioannis Chronis, ${ }^{1}$ Sevasti-Kiriaki Zervou, ${ }^{2}$ Christophoros Christophoridis, ${ }^{2}$ \\ Korina Manolidi, ${ }^{2}$ Chrysoula Ntislidou, ${ }^{1}$ Theodoros M. Triantis, ${ }^{2}$ Triantafyllos Kaloudis, ${ }^{3}$ Anastasia Hiskia, ${ }^{2}$ \\ Ifigenia Kagalou, ${ }^{4}$ Maria Lazaridou ${ }^{1}$
}

${ }^{1}$ School of Biology, Aristotle University of Thessaloniki, 54124 Thessaloniki, Greece; ${ }^{2}$ Institute of Nanoscience and Nanotechnology, NCSR "Demokritos", Athens, Greece; ${ }^{3}$ Water Quality Department, Athens Water Supply and Sewerage Company, Athens, Greece; ${ }^{4}$ Management Body of Ecodevelopment Area of Karla, Mavrovouni, Kefalovriso, Velestino, Stefanovikio 37500, Greece *Corresponding author: sgkelis@bio.auth.gr

\begin{abstract}
Lake Karla (Central Greece) is a unique example - at European scale - of a shallow lake ecosystem that was dried in the 1960s and in 2009 started to be restored. The lake is listed in the network of the Greek protected areas as it is considered a vital aquatic ecosystem, in terms of biodiversity. It has, however, already been adversely affected by both agricultural and industrial land uses in the surrounding area, leading to eutrophication and shifting algal community towards bloom-forming toxic cyanobacterial species. After repeated heavyblooms, cyanotoxin occurrence and mass fish kills, the local ecosystem management authority has implemented a water quality monitoring program (July 2013 - July 2015) to assess environmental pressures and the response of aquatic biota in the lake. Microscopic, immunological, and molecular techniques combined with physico-chemical parameters, complemented by liquid chromatography tandem mass spectrometry (LC-MS/MS), were used to monitor cyanobacteria blooms and the associated cyanotoxin production from three different sites in Lake Karla and from the adjacent Kalamaki Reservoir. Water quality was also assessed by the structure of benthic invertebrate community on the sediment. Cyanobacteria were the main phytoplankton component, representing more than $70 \%$ of the total phytoplankton abundance; dominant taxa belonged to Cylindrospermopsis raciborskii, Limnothrix redekei, Anabaenopsis elenkinii, and Microcystis spp. Euglenophytes (Euglena), diatoms (Nitzschia), and chlorophytes (Scenedesmus) were also important phytoplankton constituents. LC-MS/MS confirmed the co-occurrence of microcystins, cylindrospermopsin, saxitoxin, neo-saxitoxin and anatoxin-a. The occurrence of cyanotoxins in relation to the persistent and dominant cyanobacteria and the impact of cyanobacterial harmful algal blooms on the newly constructed lake along with the land uses and the emergent mitigation measures are discussed.
\end{abstract}

Key words: Cyanobacteria; microcystins; saxitoxin; anatoxin-a; cylindrospermopsin; nutrient loads.

Received: 17 October 2016. Accepted: 8 March 2017.

\section{INTRODUCTION}

Over the past centuries accelerated land use change and over-enrichment of nutrients mainly associated with urban, agricultural and industrial activities have promoted eutrophication of freshwater ecosystems (Chamoglou et al., 2014). Recent research suggests that eutrophication and climate change are two processes that increase rates of primary production, shifting algal community towards bloom-forming and cyanobacterial species (O'Neil et al., 2012; Papadimitriou et al., 2013; Gkelis et al., 2014). Cyanobacterial Harmful Algal Blooms (or CyanoHABs) represent one of the most conspicuous waterborne microbial hazards to human and agricultural water supplies, fisheries production, and freshwater and marine ecosystems (Codd et al., 2005; Paerl et al., 2011). This hazard results from the production of cyanotoxins, harmful secondary metabolites, such as microcystins (MCs), saxitoxin (STX), anatoxin-a (ATX-a), and cylindrospermopsins (CYNs), which can have deleterious effects within reservoirs and in downstream receiving water systems during releases (Paerl and Otten, 2013) and pose a threat for living organisms including humans (Testai et al., 2016).

Numerous factors such as water temperature, light attenuation, vertical water mixing and turbidity, flushing rates, residence time, nutrient levels and ratios affect phytoplankton assemblage and biomass composition (i.e., $\mathrm{N}_{2}-$ fixing $v s$ non-fixing cyanobacteria) (Dokulil and Teubner, 2000; Reynolds et al., 2002; O'Neil et al., 2012; Pearl, 2014). The warm Mediterranean climate favors cyanobacteria blooms in eutrophic waters, which may start in spring and last until December or even throughout the year in hypertrophic lakes (Cook et al., 2004; Gkelis et al., 2014). In Greece, extensive CyanoHABs dominated by Microcystis, Dolichospermum (Anabaena), Cylindrospermopsis, Aphanizomenon, Planktothrix, and Limnothrix species occur at eutrophic freshwaters, producing MCs, STX and CYN (Gkelis et al., 2005; 2014; 2015; Gkelis 
and Zaoutsos, 2014). At present, prediction, prevention and successful elimination of cyanobacterial blooms are still difficult (Pearl, 2014; Cirés and Ballot, 2016) despite the extensive studies and present knowledge on cyanobacteria ecology (Dokulil and Teubner, 2000; O'Neil et al., 2012; Pearl, 2014).

Lake Karla (Central Greece) is a unique example - at European scale - of a shallow lake ecosystem that was dried in 1960s and is currently undergoing its final re-construction phase for establishing a 'new' ecosystem (Sidiropoulos et al., 2012). Lake Karla is one of the most important environmental projects in the region, possibly in the whole country, that has been planned to reverse the adverse environmental conditions, caused by the lake drainage (Loukas et al., 2007). Its restoration was considered of high importance by the European Union as it would offer multi-services i.e. social, economic and ecological sustainable development to the region and not just creating a new reservoir. Lake Karla is listed in the network of the Greek protected areas (it is a Natura site (GR1420004), a Ramsar site, and a Special Protected Area site for birds). It has, however, experienced adverse effects already from the first year of its refilling, as toxinproducing cyanobacterial blooms (Oikonomou et al., 2012; Gkelis and Zaoutsos, 2014) and fish mortalities or considerable amounts of MCs in fish species have been detected (Papadimitriou et al., 2013).

In this work our goal was to assess the water quality in the Mediterranean, shallow, eutrophic Lake Karla and the adjacent Kalamaki Reservoir (Central Greece) in relation to critical environmental parameters using a multi-approach methodology. Physico-chemical parameters combined with biotic parameters (phytoplankton and benthic macroinvertebrates), immunological (ELISA), analytical (LC-MS/MS) and molecular techniques (PCR) were used to monitor cyanobacteria blooms and the associated cyanotoxin production on a seasonal basis for two years.

\section{METHODS}

\section{Study area}

The study was conducted in Lake Karla located in central Greece $\left(39^{\circ} 29^{\prime} 02^{\prime \prime} \mathrm{N}, 22^{\circ} 51^{\prime} 41^{\prime \prime} \mathrm{E}\right)$. Lake Karla is an ancient lake known from the Homeric Epics as Lake Boebeïs (Iliad II.715), which was dried up in 1962 for reclaiming agricultural land and fight floods and malaria. Its refilling started at 2010 and the suggested plan proposed the creation of a reservoir of about $38 \mathrm{~km}^{2}$. It has a $288-\mathrm{km}$ perimeter and occupies ca. 1/4 of the old Lake Karla which covered $180 \mathrm{~km}^{2}$. The hydrological basin of Lake Karla covers $1660 \mathrm{~km}^{2}$ and the maximum water volume is estimated at $184,000,000 \mathrm{~m}^{3}$. Elevation ranges from $50 \mathrm{~m}$ to more than $2000 \mathrm{~m}$, and the mean elevation of the region is about $230 \mathrm{~m}$. It is a shallow lake with a current (2013-2015) maximum water depth of 1-1.5 m. The hydrological regime of the lake is determined by inputs (rainfall on the lake and tributary inflows) and the outputs (evaporation). At present, the main water source for Lake Karla is Pinios River. According to the revised restoration plan, two main ditches transfer the flood runoff of Pinios River to the reservoir, as it is located in the lower part of Karla basin simulating the pre-disturbance conditions. Also, four collector channels concentrate the surface runoff from the higher elevation zones of the watershed and directly divert it into the reservoir. The surface runoff of the lower elevation areas will be pumped into the reservoir. So, the maximum allowable volume of the reservoir will reach up to $180 \mathrm{hm}^{3}$, but only the $60 \mathrm{hm}^{3}$ will be available to fulfill irrigation needs of the surrounding agricultures because of the environmental restraints, as the primary service of the reservoir will be the establishment of a new wetland. The lake also receives the surface runoff from the surrounding area - which is mainly agricultural and stockbreeding - and the inflows of perennial streams that drain from the surrounding mountainous land (Sidiropoulos et al., 2012). The lake has no natural outflow and the constructed channel draining to the adjacent Pagasitikos bay is closed for the present.

Kalamaki is the oldest and the largest reservoir in the basin of Lake Karla. Today's purpose of Kalamaki Reservoir is to keep water for irrigation of the surrounding agricultural area. This reservoir is not included in National Monitoring Program (EGY, 2013) and it is not characterised as water body in the national inventory. However, it is connected with Lake Karla with a complex irrigation and drainage network and therefore directly affects the physico-chemical and biological quality of Karla's basin because the water that circulates in the basin, remains for a long time in Kalamaki Reservoir.

\section{Sample collection, preparation and chemical analysis}

Sampling was taking place bimonthly for the warm period of the year (May-September) and seasonally for the cold period (November-May) during a two-year survey (July 2013-July 2015). Water samples were collected from the whole water column from three sampling stations in Lake Karla (KL1, KL2, KL3) and from the surface of one offshore station in Kalamaki Reservoir (KK) (Fig. 1) using a 1m-long Niskin-type sampler and a plastic $10 \mathrm{~L}$ vessel, respectively. After August 2013, the water level fell in Lake Karla (KL1, KL2, and KL3 stations) and varied between 0.8-1.2 m. In Lake Kalamaki (KK station) depth varied between 0.4-0.9 m. After the water level decrease in Karla no vessel could enter the lake, therefore sampling was performed by walking. While sampling, extra care was taken to avoid sediment resuspension (after reaching the sampling point researchers waited $10 \mathrm{~min}$ before collecting the sam- 
ple). Water transparency was measured using a $20-\mathrm{cm} \mathrm{Sec-}$ chi disk. Temperature, $\mathrm{pH}$, conductivity, turbidity, and dissolved oxygen were measured in situ using the AquaRead AP-2000 probe (Kent, GB). Concentrations of Total Phosphorus $(\mathrm{TP})$ in lake water and nitrate $\left(\mathrm{NO}_{3}-\mathrm{N}\right)$, nitrite $\left(\mathrm{NO}_{2}-\right.$ $\mathrm{N})$, ammonia $\left(\mathrm{NH}_{4}-\mathrm{N}\right)$, and soluble reactive phosphorus (SRP) in filtrates were processed and analyzed in situ spectrophotometrically using AQUA NOVA 60A and MERCK standards. Three sub-samples of $500 \mathrm{~mL}$ each (two fixed with Lugol's solution and formaldehyde and one retained fresh) were collected in polyethylene bottles and used for microscopic analysis.

Sub-samples $(50-300 \mathrm{~mL})$ were filtered through Whatman $\mathrm{GF} / \mathrm{C}$ filters. Filter papers and filtrates were stored at $-20^{\circ} \mathrm{C}$ for subsequent cyanotoxin analysis and DNA extraction. The Carlson Trophic State Index (TSI) was used as an additional estimator of eutrophication based on abiotic characteristics of the freshwaters surveyed; it was calculated based on TP using the simplified equation given by Cooke et al., (1986): TSI $=14.42 * \ln [\mathrm{TP}]=4.15$.

Benthic macroinvertebrates were sampled from the soft bottom of Lake Karla in three replicates for each sampling station (KL1, KL2, and KL3) with an Ekman-Birge grab (225 $\mathrm{cm}^{2}$ sampling area). In Kalamaki Reservoir, benthic macroinvertebrates were collected with a handnet because the substrate was coarse: a $250 \mathrm{~mm} \times 230 \mathrm{~mm}$, D-shaped pond net $(0.9 \mathrm{~mm}$ mesh size, ISO 7828:1985; EN 27828:1994) was used according to the semi-quantitative 3-min kick/sweep method (Armitage and Hogger, 1994). Then, they were sieved with a $200-\mathrm{mm}$ mesh and fixed in $10 \% \mathrm{v} / \mathrm{v}$ neutralised formaldehyde.

\section{Phytoplankton analysis}

Fresh, Lugol and formaldehyde preserved samples were examined using a Zeiss Axio imager z2 (Carl Zeiss, Jena, Germany) microscope and an inverted microscope (Olympus IX71). Phytoplankton species were identified using taxonomic keys (Komárek and Anagnostidis, 1999, 2005; Komárek, 2013). Phytoplankton abundance was determined in Lugol samples with the Utermöhl method (Utermöhl, 1958). Mean cell or filament volume was calculated using geometric formulae after measuring the dimensions of at least 30 individuals (cells or filaments) of each species with an Axio Cam MRc5 digital camera (Carl Zeiss). The calculated biovolume concentrations were expressed as biomass per liter $\left(\mathrm{mg} \mathrm{L}^{-1}\right)$ by assuming a specific density of $1 \mathrm{~g} \mathrm{~cm}^{-3}$. Species and taxonomical groups comprising
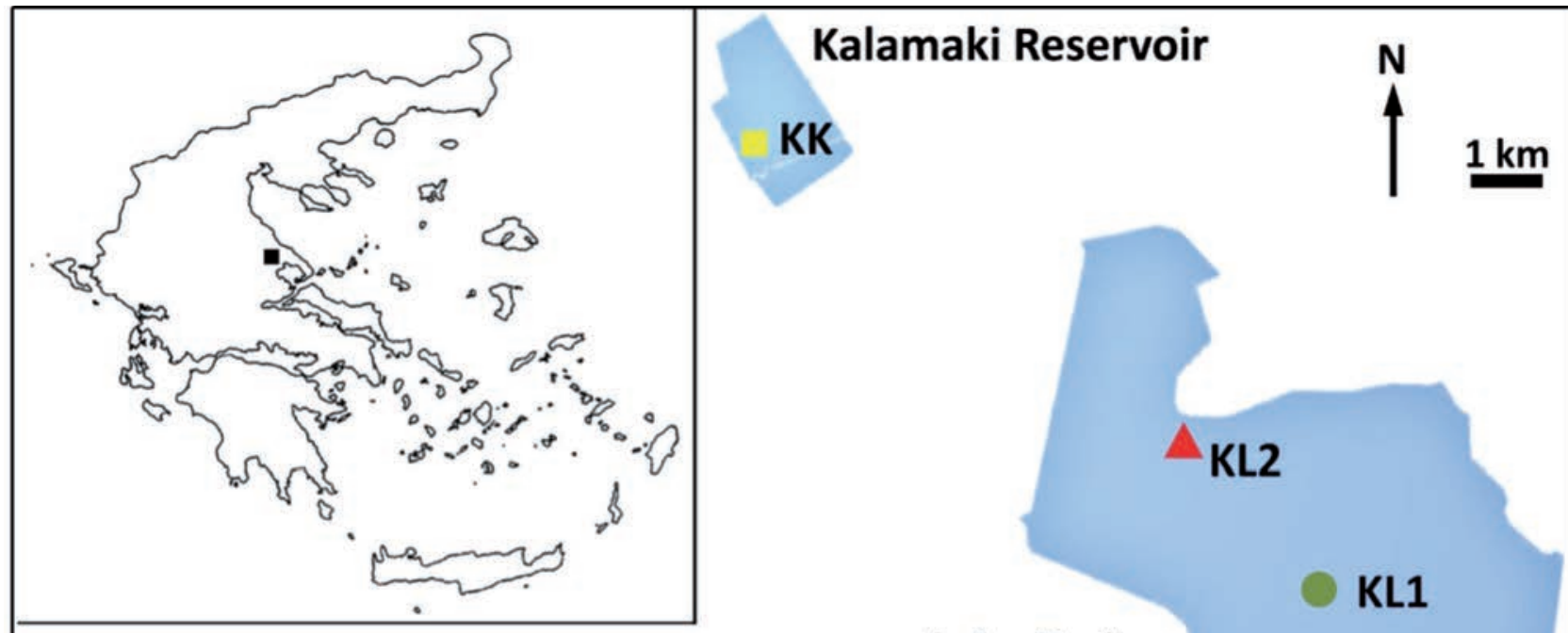

Lake Karla

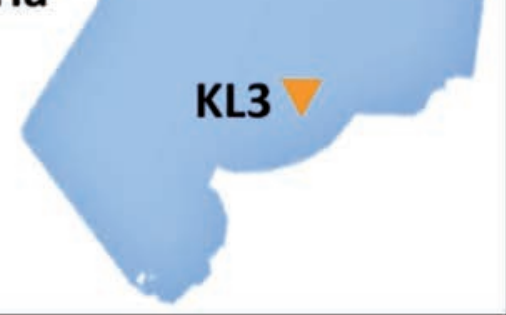

Fig. 1. Map of Lake Karla and Kalamaki Reservoir showing the four sampling stations (KK, KL1, KL2, KL3). Insert, map of Greece (solid square indicates the location of the two waterbodies). 
more than $10 \%(\mathrm{w} / \mathrm{w})$ of the total phytoplankton biomass were considered to be dominant. Phytoplankton species were classified to functional groups according to Reynolds et al. (2002). Cyanobacterial biomass was used to assess the water quality by using: i) the two most relevant grades ('tolerable' and 'bad' corresponding to $>8$ and $>16 \mathrm{mg} \mathrm{L}^{-1}$ of phytoplankton biomass, respectively) given in Padisák et al. (2006) for the big shallow lakes of Central Europe; and ii) the Good/Moderate (G/M) grade (corresponding to $\leq 1 \mathrm{mg} \mathrm{L}^{-1}$ of phytoplankton biomass) given by the Mediterranean Geographical Intercalibration Group (JRC European Commission, 2009); cyanobacteria biomass accounted for more than $80 \%$ of the whole phytoplankton biomass, thus was considered representative. Cyanobacterial biomass was also compared to the World Health Organization Guidance Levels 2 and 3 for recreational waters (WHO, 2003), which correspond to 10 and $200 \mathrm{mg} \mathrm{L}^{-1}$, respectively, after converting cyanobacterial cell concentration (cells $\mathrm{mL}^{-1}$ ) to biovolume (mg L$\left.{ }^{-1}\right)$ according to Bartram et al. (1999).

\section{Benthic macroinvertebrates}

Macroinvertebrates were sorted and identified to genus or species level. Chironomids and oligochaetes were slide-mounted prior to determination. For the identification of chironomids (larvae and pupae) and oligochaetes the keys of Wiederholm (1983 and 1986) and of Timm (2009) were used, respectively. Immature stages were identified by the particular characters of the setae.

\section{DNA extraction and molecular analyses}

In order to identify potentially toxic cyanobacteria, different primer pairs, previously described in the literature, were used to detect different gene targets known to be involved either in the biosynthesis of MC, CYN or
STX. DNA was extracted using the protocol described in Atashpaz et al. (2010) for Gram negative bacteria, after slicing the two offshore sampling stations (station 3 and station 4) filters with a sterile scalpel. PCR was carried out on the DNA extracts using the primer pairs shown in Tab. 1 and PCR conditions described in detail by Gkelis and Zaoutsos (2014). All primer pairs were specific for the gene region each one amplifies. Thermal cycling was carried out using an Eppendorf MasterCycler Pro (Eppendorf). PCR products were separated by $1.5 \%(\mathrm{w} / \mathrm{v})$ agarose gel in $1 \mathrm{X}$ TAE buffer. The gels were stained with ethidium bromide and photographed under UV transillumination.

DNA extracted from Microcystis aeruginosa M6 strain was used as positive control for the amplification of $m c y A, m c y B$ and $m c y E / n d a F$ gene targets; DNA from Cylindrospermopsis raciborskii Aqs strain was used as positive control for the amplification of the $p s$ (peptide syntethase) and pks (polyketide synthase) genetic determinants; DNA from Aphanizomenon gracile A040 strain was used as positive control for the detection of sxtI target gene (see Vasconcelos et al., 2010). DNA of control strains was extracted as described earlier from lyophilized biomass provided by Prof. Vitor Vasconcelos (CIIMAR, University of Porto, Portugal).

\section{Cyanotoxin analysis}

The Abraxis Microcystin (520011), Saxitoxin (52255B), and Cylindrospermopsin (522011) Microtiter Plate Kits were used to determine the presence of MCs, STXs, and CYNs, respectively in sampling stations KL1, KL3, and $\mathrm{KK}$. Toxins from filters (i.e., representing the intracellular fraction) were extracted by eight $\mathrm{mL}$ of water in glass tubes, immersed in ice and sonicated for $10 \mathrm{~min}$, after slicing the filters with a sterile scalpel. After sonication, the mixture

Tab. 1. PCR primers used in the analyses of water samples collected from Lake Karla and Kalamaki Reservoir for the detection of genes involved in MC, CYN and STX production.

\begin{tabular}{|c|c|c|c|c|}
\hline Primer & Target-gene & Sequence $\left(5^{\prime}-3^{\prime}\right)$ & Size (bp) & Reference \\
\hline $\begin{array}{l}\text { mcyA-Cd1F } \\
\text { mcyA-Cd1R }\end{array}$ & $m c y A$ & $\begin{array}{l}\text { AAAATTAAAAGCCGTATCAAA } \\
\text { AAAAGTGTTTTATTAGCGGCTCAT }\end{array}$ & 297 & Hisbergues et al., 2003 \\
\hline $\begin{array}{l}\text { mcyB2959F } \\
\text { mcyB3278R }\end{array}$ & $m c y B$ & $\begin{array}{l}\text { TGGGAAGATGTTCTTCAGGTATCCAA } \\
\text { AGAGTGGAAACAATATGATAAGCTAC }\end{array}$ & 320 & Nonneman and Zimba, 2002 \\
\hline $\begin{array}{l}\text { PKEF1 } \\
\text { PKER1 }\end{array}$ & $m c y E$ & $\begin{array}{l}\text { CGCAAACCCGATTTACAG } \\
\text { CCCCTACCATCTTCATCTTC }\end{array}$ & 755 & Ouahid et al., 2005 \\
\hline $\begin{array}{l}\text { HEPF } \\
\text { HEPR }\end{array}$ & $m c y E / n d a F$ & $\begin{array}{l}\text { TTTGGGGTTAACTTTTTTGGGCATAGTC } \\
\text { AATTCTTGAGGCTGTAAATCGGGTTT }\end{array}$ & 472 & Jungblut and Neilan, 2006 \\
\hline $\begin{array}{l}\text { psM13 } \\
\text { psM14 }\end{array}$ & ps & $\begin{array}{l}\text { GGCAAATTGTGATAGCCACGAGC } \\
\text { GATGGAACATCGCTCACTGGTG }\end{array}$ & 597 & Schembri et al., 2001 \\
\hline $\begin{array}{l}\text { pksK18 } \\
\text { pksM4 }\end{array}$ & pks & $\begin{array}{l}\text { CCTCGCACATAGCCATTTGC } \\
\text { GAAGCTCTGGAATCCGGTAA }\end{array}$ & 422 & Fergusson and Saint, 2003 \\
\hline $\begin{array}{l}\text { Sxt1-F } \\
\text { Sxt1-R }\end{array}$ & sxtI & $\begin{array}{l}\text { GCTTACTACCACGATAGTGCTGCCG } \\
\text { GGTTCGCCGCGGACATTAAA }\end{array}$ & 1669 & Kellmann et al., 2008 \\
\hline
\end{tabular}


was stirred for $30 \mathrm{~min}$ at room temperature, centrifuged for $10 \mathrm{~min}$ at $13,000 \mathrm{~g}$ and the supernatant was collected. The pellet was resuspended in eight $\mathrm{mL}$ of water and re-extracted. The resulting solutions were pooled together, dried in an air stream, and the residue was dissolved in $1 \mathrm{~mL}$ Milli-Q water; then, they were applied to the above mentioned ELISA kits following the manufacturer's instructions. Extracellular cyanotoxins were measured by applying the filtrates to ELISA. All microtiter plates were read at $450 \mathrm{~nm}$ and $\mathrm{B} / \mathrm{B}_{0}$ values $(\%)$ were calculated. Samples with a coefficient of variation percentage of $>15 \%$ were not accepted. Dilutions of extracts until they fit each kit's standard curve range were preformed when necessary. Results are given in $\mu \mathrm{g}$ of toxin-equivalent (eq.) per $\mathrm{L}$ of water (e.g., eq. $\mu \mathrm{g} \mathrm{MC}$ $\mathrm{L}^{-1}$ ). The detection limits for MC, STX, and CYN assays, are $0.10 \mu \mathrm{g} \mathrm{L}^{-1}, 0.015 \mu \mathrm{g} \mathrm{L}^{-1}$, and $0.040 \mu \mathrm{g} \mathrm{L}^{-1}$, respectively.

In order to confirm the ELISA results and verify the identities of cyanotoxins, 13 out of the previously mentioned filter-extracts (intracellular toxins) were analyzed without further pretreatment, using liquid chromatography-tandem mass spectrometry (LC-MS/MS). Determination was carried out on a Finnigan TSQ Quantum Discovery Max triple-stage quadrupole mass spectrometer (Thermo Fischer Scientific, Waltham, MA, USA), equipped with electrospray ionization (ESI) source. Separation of target analytes was achieved with a Finnigan Surveyor LC system, equipped with a Finnigan Surveyor AS autosampler (Thermo Fischer Scientific). Detection was performed in multiple reaction monitoring (MRM) mode. Xcalibur software 2.1 SP 1160 was used to control the mass spectrometer and for data acquisition.

The determination of CYN, ATX-a, and MCs ([DAsp $\left.{ }^{3}\right]$ MC-RR, MC-RR, MC-YR, MC-HtyR, [DAsp ${ }^{3}$ ]MC-LR, MC-LR, MC-HilR, MC-WR, MC-LA, MC-LY, MC-LW, MC-LF) was carried out according to the LC-MS/MS method described by Zervou et al. (2017). The same extracts were also analysed for STX and neoSTX with an in-house developed method (MoustakaGouni et. al., 2016), using a SeQuant ZIC-Hydrophilic Interaction Chromatographic (HILIC) column (150 x 2.1 $\mathrm{mm}, 3.5 \mu \mathrm{m}$ column) supplied by Merck.

The method limits of detection (LOD) and method limits of quantification (LOQ) for each cyanotoxin analyzed referring to $50 \mathrm{~mL}$ of water concentrated to a final volume of $1 \mathrm{~mL}$ are given in Supplementary Tab. 1. A representative chromatogram of Sample KK (26-7-2013) is given in Supplementary Fig. 1. Cyanotoxin concentrations are given in $\mu \mathrm{g} \mathrm{L}^{-1}$.

\section{Statistical analyses}

A one-way ANOVA test was used to compare the means of physical, chemical and biological parameters among sampling stations, after check for normality (Shapiro-Wilk test) and equality of variances (Levene sta- tistic). Spearman's rank correlation coefficient (r) was used to determine correlation between variables. Analyses were performed with SPSS 23.0 (IBM SPSS statistics).

\section{RESULTS}

\section{Physical-chemical parameters}

There was a strong seasonal cycle of water temperature ranging from $14^{\circ} \mathrm{C}$ to $31^{\circ} \mathrm{C}$ except in February 2015 where temperature fell to $5^{\circ} \mathrm{C}$ (Fig. 2a). The $\mathrm{pH}$ values ranged from 7.1 to 9.5, with a maximum of 10.6 in September 2014 at KL1 station (Fig. 2b). Dissolved oxygen varied noticeably in time and space, decreasing to $<7 \mathrm{mg}$ $\mathrm{L}^{-1}$ at some stations during the warm months (Fig. 2c). Conductivity was very high throughout the whole study period, significantly higher (ANOVA, $\mathrm{P}<0.05$ ) in Lake Karla compared to Kalamaki Reservoir (Fig. 2d). Water transparency was low $(<35 \mathrm{~cm})$ throughout the whole study period (Fig. 2e). Turbidity was relatively low until mid-2014 where a sharp peak was recorded, after which it stayed high for the rest of the study period (Fig. 2f).

With regard to nutrient concentrations, nitrite nitrogen $\left(\mathrm{NO}_{2}-\mathrm{N}\right)$ was very low and reached undetectable concentrations in all stations until May 2014, after which it rose and reached a peak of $2.5 \mathrm{mg} \mathrm{L}^{-1}$ at May 2015 (Fig. 3a). Nitrate $\left(\mathrm{NO}_{3}-\mathrm{N}\right)$ and ammonia $\left(\mathrm{NH}_{4}-\mathrm{N}\right)$ nitrogen were very high and exhibited temporal and spatial variation (Fig. 3 $\mathrm{b}, \mathrm{c})$. Ammonia nitrogen was the most important form in the DIN pool. DIN concentration ranged from $500 \mu \mathrm{g} \mathrm{L}^{-1}$ at the beginning of the study to $>15 \mathrm{mg} \mathrm{L}^{-1}$ (July-November 2015) (Fig. 2d). SRP and TP concentrations were high and varied between undetectable concentrations (NovemberMay 2014) and $3 \mathrm{mg} \mathrm{L}^{-1}$ (in September 2013) (Fig. 3 e,f). The DIN/SRP was generally low and below the 10 threshold, except between July-November 2014 (Fig. 4a).

\section{Phytoplankton}

A total of 44 phytoplankton species were identified in the lake water samples during the study period (Tab. 2). Cyanobacteria were the taxonomic group with the highest number of species (23), followed by chlorophytes (13), diatoms (6), cryptophytes (1), and euglenophytes (1). Cyanobacteria dominated the phytoplankton's biomass (Fig. 5). Phytoplankton blooms were observed in Lake Karla and Kalamaki Reservoir almost throughout the whole monitoring period with cyanobacteria consisting on average ca. $85 \%$ of the total phytoplankton biomass (Fig. 5).

Total cyanobacterial biomass ranged from 15 to $230 \mathrm{mg}$ $\mathrm{L}^{-1}$ reaching its peak at September 2013 (KL1 and KK stations), February 2013 (KK) and July 2014 (KL1) (Fig. 6). The biomass temporal variation was not the same in the two years of monitoring: After the warm period of 2013 showed a decrease in November to reach high values dur- 

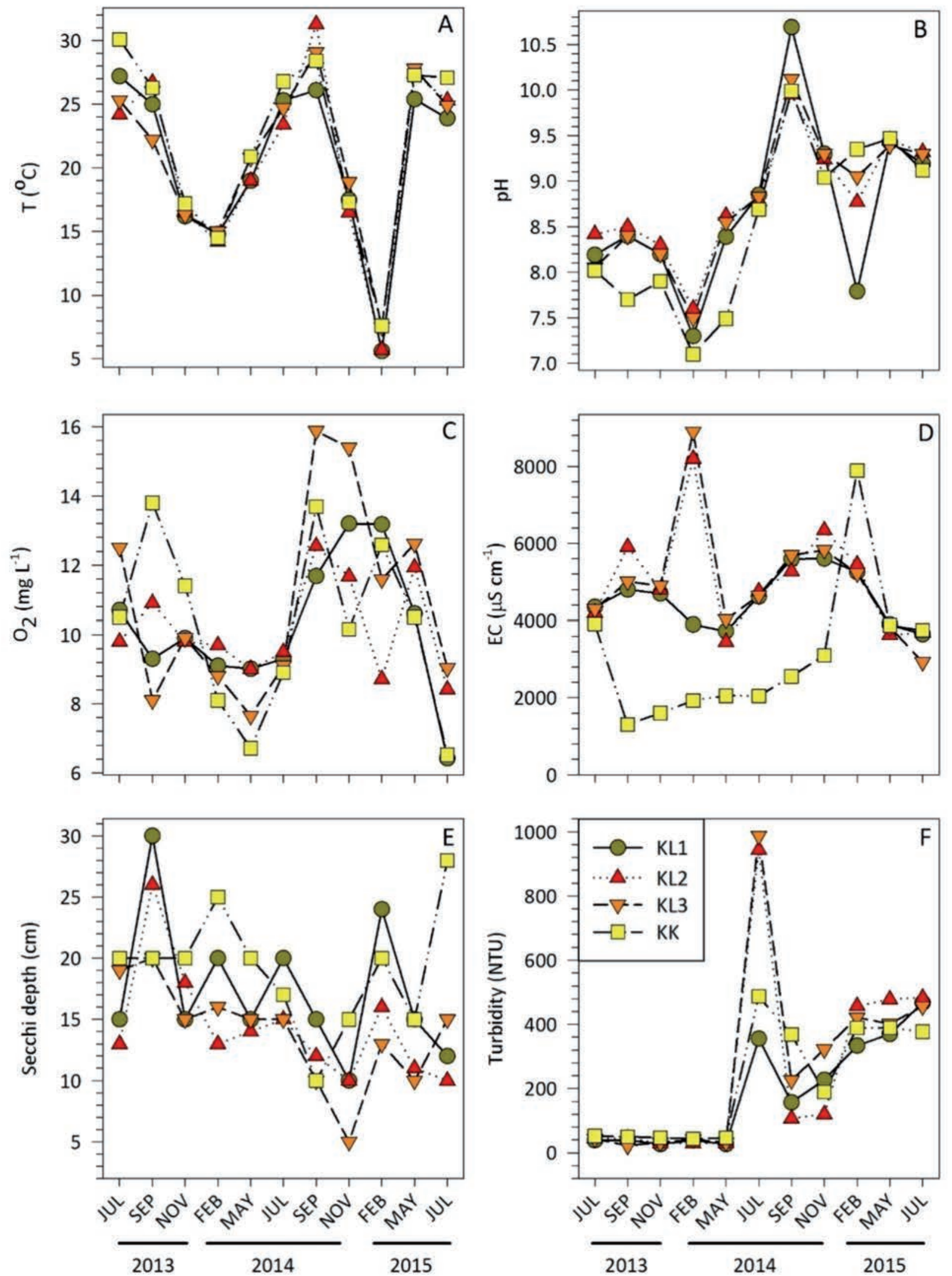

Fig. 2. Physical and chemical parameters in Lake Karla (KL1, KL2, KL3) and Kalamaki Reservoir (KK) from July 2013 to July 2015. A) Temperature; B) pH; C) dissolved oxygen; D) conductivity; E) transparency; F), turbidity. 
ing the cold period (February-May) of 2014. The rapid decrease of temperature in November 2014 combined with the high turbidity coincided with the lower biomass values (except KL1 station) in the warm period in 2014; biomass remained low until the end of the monitoring program in July 2015. Biomass was negatively but not highly correlated with $\mathrm{pH}, \mathrm{DO}, \mathrm{NO}_{3}-\mathrm{N}, \mathrm{NO}_{2}-\mathrm{N}$, and conductivity (Supplementary Tab. 2). The biomass was significantly higher
$(\mathrm{P}<0.05)$ in Kalamaki Reservoir $(\mathrm{KK})$ and Lake Karla KL1 station compared to KL2 and KL3 stations. All biomass values exceeded the Good/Moderate and Bad threshold for ecological status, as well as the WHO Guidance Level 2; during the warm period the biomass also exceeded the WHO Guidance Level 3 (Fig. 4b).

In both waterbodies nitrogen-fixing Nostocales cyanobacteria were dominant throughout the study period

Tab. 2. Phytoplankton taxa identified in Lake Karla and Kalamaki Reservoir during the study period.

\section{Taxa}

Cyanobacteria (23)

Anabaenopsis elenkinii V.V.Miller 1923

Aphanizomenon sp.

Aphanocapsa sp.

Arthrospira sp.

Chroococcus sp.

Cuspidothrix issatchenkoi (Usacev) Rajaniemi, Komárek, Willame, Hrouzek, Kastovská, Hoffmann et Sivonen 2005

Cylindrospermopsis raciborskii (Woloszynska) Seenayya et Subba Raju 1972

Dolichospermum spp.

Gloeocapsa sp.

Gomphosphaeria sp.

Limnothrix redekei (Van Goor) Meffert 1988

Merismopedia sp.

Microcystis aeruginosa (Kützing) Kützing 1846

Microcystis flos-aquae (Wittrock) Kirchner 1898

Microcystis sp.

Planktolyngbya $\mathrm{cf}$. limnetica

Planktothrix agardhii (Gomont) Anagnostidis et Komárek 1988

Pseudanabaena limnetica (Lemmermann) Komárek 1974

Pseudanabaena mucicola (Naumann et Huber-Pestalozzi) Schwabe 1964

Radiocystis geminata Skuja 1948

Snowella litoralis (Häyrén) Komárek et Hindák 1988

Sphaerospermopsis aphanizomenoides (Forti) Zapomelová, Jezberová, Hrouzek, Hisem, Reháková et Komárková 2012

Synechococcus sp.

Chlorophyta (13)

Chlamydomonas sp.

Chlorella sp.

Chlorococcum citriforme Archibald et Bold 1970

Coelastrum sp.

Desmodesmus communis (E. Hegewald) E.Hegewald 2000

Dictyosphaerium pulchellum H.C. Wood 1873

Gloeocystis sp.

Monoraphidium sp.

Pediastrum boryanum (Turpin) Meneghini 1840

Selenastrum sp.

Spirogyra sp.

Tetraëdron minimum (A.Braun) Hansgirg 1888

Tetrastrum komarekii Hindák 1977

Diatoms (6)

Aulacoseira granulata (Ehrenberg) Simonsen 1979

Cyclotella sp.

Nitzschia acicularis (Kützing) W. Smith 1853

Nitzschia closterium (Ehrenberg) W. Smith 1853

Stephanodiscus sp.

Synedra sp.

Cryptophyta (1)

Rhodomonas sp.

Euglenophyta (1)

Euglena acus 

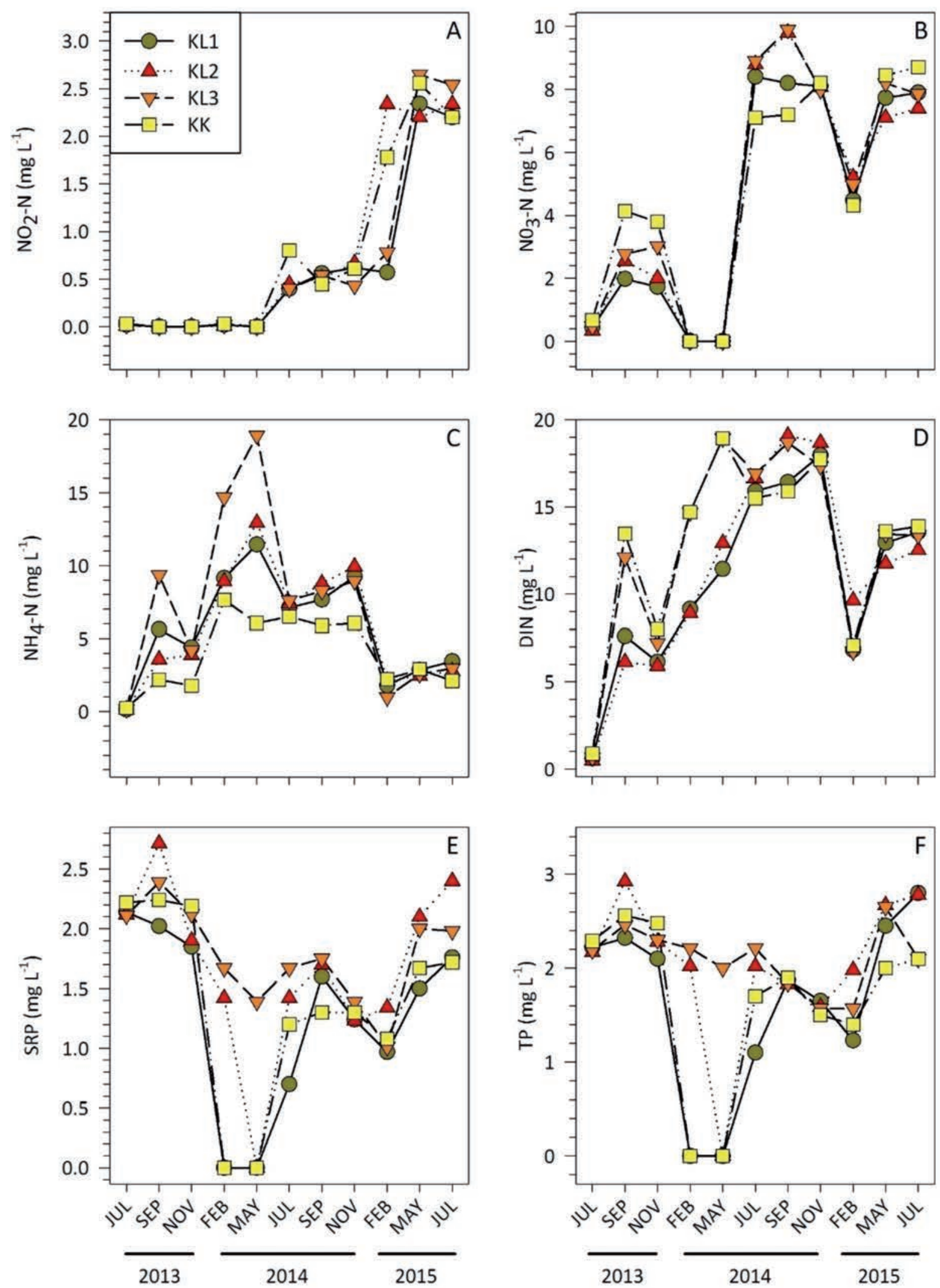

Fig. 3. Nutrient loads in Lake Karla (KL1, KL2, KL3) and Kalamaki Reservoir (KK) from July 2013 to July 2015. A) Nitrite nitrogen $\left(\mathrm{NO}_{2}-\mathrm{N}\right)$; B) nitrate nitrogen $\left(\mathrm{NO}_{3}-\mathrm{N}\right)$; C) ammonia nitrogen $\left(\mathrm{NH}_{4}-\mathrm{N}\right)$; D) dissolved inorganic nitrogen (DIN); E) soluble reactive phosphorus (SRP); F) total phosphorus (TP). 
(Figs. 5 and 6). In Lake Karla, the dominant cyanobacteria were Anabaenopsis elenkinii, Sphaerospermopsis aphanizomenoides (functional group H1), Limnothrix redekei and Planktothrix cf. agardhii (functional group S1), and Cylindrospermopsis raciborskii (functional group $\mathrm{S}_{\mathrm{N}}$ ). During the warm period Microcystis aeruginosa (functional group M) was also dominant in KL2 and KL3, whereas in July 2015 in KL2 there was an almost $100 \%$ dominance of Dolichospermum (Anabaena) cf. smithii (Fig. 6). In Kala- maki Reservoir A. elenkinii, C. raciborskii, and Sph. aphanizomenoides were dominant from July 2013 to September 2014; in May 2015 D. cf. smithii became dominant whereas in July 2015 Lyngbya sp. occurred and became dominant for the first time (Fig. 6). Cyanobacteria dominated Kalamaki Reservoir even in the cold period. $A$. elenkinii, C. raciborskii, Sph. aphanizomenoides, and Dolichospermum spp. accounted for the higher biomass in KL1 and KK. Apart from cyanobacteria, the chlorophytes
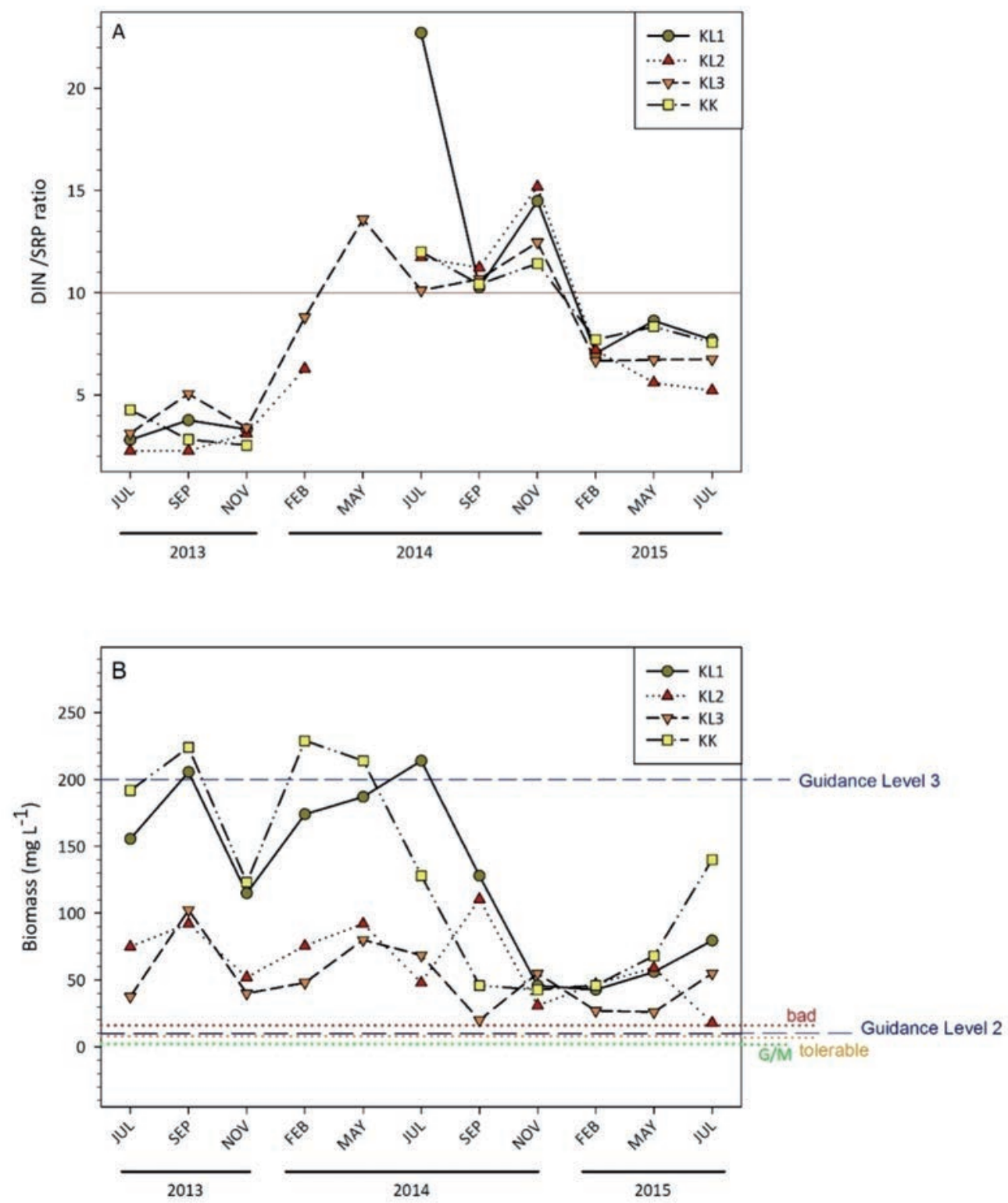

Fig. 4. Dissolved inorganic nitrogen (DIN) to soluble reactive phosphorus (SRP) ratio (A) and cyanobacteria biomass (B) in water samples collected in Lake Karla (KL1, KL2, KL3) and Kalamaki Reservoir (KK) from July 2013 to July 2015. Dotted lines represent the thresholds for ecological status based on cyanobacterial biomass given by Padisák et al. (2006) and the Mediterranean Geographical Intercalibration Group (JRC European Commission, 2009); long-dashed lines represent WHO Guidance Levels for cyanobacterial concentrations in recreational waters (WHO, 2003). 
Monoraphidium sp. (functional group X1) and Tetrastrum komarekii and the diatoms Nitzschia acicularis and Nitzschia closterium (functional group X1) were occasionally dominant in both water bodies.

\section{Benthic invertebrates}

In Lake Karla, only four taxa (Annelida, Lymnaea sp., Chironominae, and Tanypodinae) were recorded; in Kalamaki Reservoir 3 of the four taxa were found (Lymnaea sp. was absent).

\section{Molecular detection}

PCR products indicating the presence of $m c y A$, $m c y B$, and $m c y E / n d a F$ genes were obtained for most of the samples tested (Tab. 3). Only two of the assayed environmental samples gave positive PCR results for each of the psM13/PSM14 and pksM4/PKSK18 primer pairs, thus, suggesting the presence of CYN producing cyanobacteria. Eight water samples, mainly from Kalamaki Reservoir, dominated by A. elenkinii, Sph. aphanizomenoides, and $C$. raciborskii, gave a PCR product of about $1500 \mathrm{bp}$ using the sxt1F/sxt1R primer pair for the presence of the sxtI gene (Tab. 3).

\section{Cyanotoxins}

MCs were detected by ELISA in water samples collected in the warm period, whereas in the cold period they were below detection limit (Fig. 7 a,b). Intracellular MCLR eq. concentration ranged from $1 \mu \mathrm{g} \mathrm{L}^{-1}$ to $8 \mu \mathrm{g} \mathrm{L}^{-1}$ (Lake Karla) or $11.5 \mu \mathrm{g} \mathrm{L}^{-1}$ (Kalamaki Reservoir) (Fig. 7a) while extracellular $\mathrm{MC}$ concentrations exhibited similar seasonal and temporal pattern with concentrations ranging from $1 \mu \mathrm{g} \mathrm{L}^{-1}$ eq. to $4 \mu \mathrm{g} \mathrm{L}^{-1}$ (Fig. 7b). A maximum total (sum of intracellular and extracellular) $\mathrm{MC}$ concentration of $14.4 \mu \mathrm{g} \mathrm{L}^{-1}$ eq. was recorded at KK station on September 2013. The MC and CYN intracellular concentrations were positively correlated with temperature and SRP (Supplementary Tab. 2).

$\mathrm{CYN}$ was found in the warm periods at stations KL1 and KK and in November 2013 at KK (Fig. 7c). All those samples were dominated by A. elenkinii, Sph. aphanizomenoides, and C. raciborskii. STX was found in some samples in the warm period in very low concentrations, close to the detection limit, with the exception of July 2014 in Kalamaki Reservoir where it reached $0.17 \mu \mathrm{g} \mathrm{L}-1$ eq. (Fig. 7d). In this sample, A. elenkinii, Sph. aphanizomenoides, and $C$. raciborskii were also the dominant species.

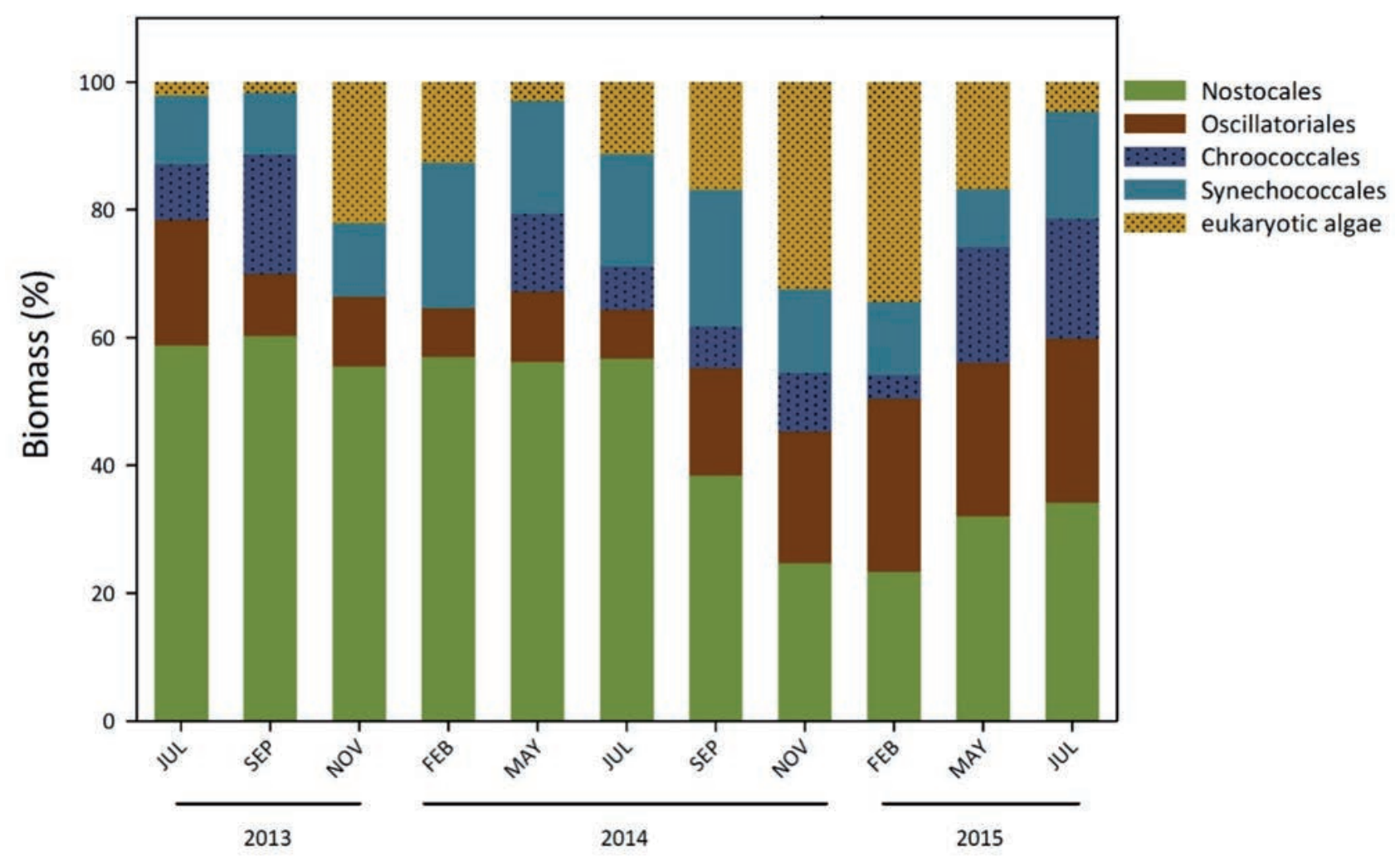

Fig. 5. Relative biomass (\%) of cyanobacteria and other algae in water samples collected from Lake Karla and Kalamaki Reservoir between July 2013 and July 2015. Values represent means of the four sampling stations. 
LC-MS/MS analysis confirmed the presence of CYN in some cases, with concentrations ranging from $0.5 \mu \mathrm{g} \mathrm{L}^{-1}$ to $12.1 \mu \mathrm{g} \mathrm{L}{ }^{-1}$ (Tab. 4). It also revealed the presence of ATX-a in 3 out of 13 samples analyzed, with concentrations ranging from $0.8 \mu \mathrm{g} \mathrm{L}^{-1}$ to $5.4 \mu \mathrm{g} \mathrm{L}^{-1}$ (Tab. 4). Again, in those samples A. elenkinii, Sph. aphanizomenoides, and C. raciborskii were the dominant species. STX was found in all of the samples analysed, whereas neo-STX was found in 7/13 samples. [D-Asp $\left.{ }^{3}\right]$ MC-RR, MC-RR, MC-YR, and MC-LR were found in trace amounts during the warm periods at stations
KL1 and KK; in November 2013 at KK, MC-YR and MCLR were found in concentrations below the quantification limit (Tab. 4). In July 2013 CYN, ATX-a, STX and/or neoSTX, and MCs co-existed in KL1 and KK.

\section{Ecological classification}

According to the Water Frame Directive terminology, the ecological status of modified lakes is expressed as ecological potential and the goal is to achieve at least

Tab. 3. PCR amplification of regions targeting genes responsible for MC ( $m c y A, m c y B$, and $m c y E / n d a F)$, CYN (ps, pks) and STX (stxI) production, in the water samples collected from Lake Karla (KL1, KL3) and Kalamaki Reservoir (KK).

\begin{tabular}{|c|c|c|c|c|c|c|c|}
\hline \multirow{2}{*}{$\begin{array}{l}\text { Collection } \\
\text { date }\end{array}$} & \multirow{2}{*}{$\begin{array}{l}\text { Sampling } \\
\text { station }\end{array}$} & \multicolumn{6}{|c|}{ Cyanotoxin genes } \\
\hline & & $m c y A$ & $m c y B$ & $m c y E / n d a F$ & PS & PKS & sxtI \\
\hline \multirow[t]{4}{*}{$26-07-13$} & KL1 & + & + & + & - & - & - \\
\hline & KL2 & + & + & - & - & - & - \\
\hline & KL3 & + & + & + & - & - & - \\
\hline & KL4 & + & + & + & - & - & - \\
\hline \multirow[t]{4}{*}{$11-09-13$} & KL1 & + & + & + & - & - & + \\
\hline & KL2 & + & + & + & - & - & - \\
\hline & KL3 & + & + & + & - & - & - \\
\hline & KK & + & + & + & - & - & + \\
\hline \multirow[t]{4}{*}{$22-11-13$} & KL1 & + & + & + & - & - & - \\
\hline & KL2 & + & + & + & - & - & - \\
\hline & KL3 & + & - & - & - & - & - \\
\hline & KK & + & + & + & - & - & - \\
\hline \multirow[t]{4}{*}{$21-02-14$} & KL1 & + & + & + & - & - & - \\
\hline & KL2 & + & + & + & - & - & + \\
\hline & KL3 & + & + & + & - & - & - \\
\hline & KK & + & + & + & - & - & - \\
\hline \multirow[t]{4}{*}{$15-05-14$} & KL1 & + & + & + & - & - & - \\
\hline & KL2 & + & + & + & - & - & - \\
\hline & KL3 & + & + & + & - & - & - \\
\hline & KK & + & + & + & - & - & - \\
\hline \multirow[t]{4}{*}{ 04-07-14 } & KL1 & + & + & + & - & - & - \\
\hline & KL2 & + & - & + & - & - & - \\
\hline & KL3 & + & + & + & - & - & - \\
\hline & KK & + & + & + & - & - & - \\
\hline \multirow[t]{4}{*}{ 04-09-14 } & KL1 & + & + & + & - & - & - \\
\hline & KL2 & + & + & + & - & - & - \\
\hline & KL3 & + & + & + & - & - & - \\
\hline & $\mathrm{KK}$ & + & + & + & - & - & - \\
\hline \multirow[t]{4}{*}{$07-11-14$} & KL1 & + & + & + & - & - & - \\
\hline & KL2 & + & - & - & - & - & - \\
\hline & KL3 & + & + & + & - & - & - \\
\hline & KK & + & + & + & - & - & + \\
\hline \multirow[t]{4}{*}{$21-02-15$} & KL1 & - & - & + & - & - & - \\
\hline & KL2 & - & - & - & - & - & - \\
\hline & KL3 & - & - & + & - & - & - \\
\hline & $\mathrm{KK}$ & - & - & + & - & - & - \\
\hline \multirow[t]{4}{*}{$15-05-15$} & KL1 & - & - & - & - & - & - \\
\hline & KL2 & + & + & + & - & - & - \\
\hline & KL3 & - & - & - & - & - & - \\
\hline & $\mathrm{KK}$ & + & + & + & - & + & + \\
\hline \multirow[t]{4}{*}{$01-07-15$} & KL1 & - & - & - & + & - & + \\
\hline & KL2 & - & - & - & + & - & + \\
\hline & KL3 & - & - & - & - & - & + \\
\hline & KK & + & + & + & - & + & - \\
\hline
\end{tabular}


Good Ecological Potential. Considering the parameters: i) very high phytoplankton biomass (Fig. 4b); ii) dominance of cyanobacteria in phytoplankton (Fig. 5); iii) functional groups dominating the phytoplankton (Fig. 6); iv) low diversity of macroinvertebrate taxa; v) frequency and intensity of water blooms; and vi) presence of multiple cyanotoxins (Fig. 7, Tab. 4), the ecological potential in Lake Karla and Kalamaki reservoir is classified as poor.

\section{DISCUSSION}

This study presents the simultaneous investigation of the phytoplankton, macroinvertebrate community, and the presence of cyanotoxins in relation with key limnological features (nutrients, temperature, $\mathrm{pH}$, etc.) in a recently restored, highly eutrophic to hypertrophic (Chamoglou et al., 2014; Theologou et al., 2016) shallow Mediterranean lake. In Lake Karla and Kalamaki Reservoir dense blooms dominated by cyanobacteria were observed throughout the year, in accordance with previous findings in other eutrophic freshwaters of Greece (Cook et al., 2004; Gkelis et al., 2014). Mediterranean lakes are subjected to large variations in water level, determined by naturally intraand inter-annual variations in rainfall and groundwater discharge or recharge in alternating drought and wet periods (Beklioglu et al., 2007). Temperature variations may have considerable further effects on the lake's ecosystem structure and dynamics; for example, their response to eutrophication seems to be quite different from that of the cold temperate in Northern Europe: nutrients can limit phytoplankton biomass throughout the year at low latitudes (Moustaka- Gouni et al., 2014). Prolonged hy- draulic retention time because of drought, results in increased salinity with secondary effects on biota, ion toxicity and osmotic stress (Jeppesen et al., 2007). Such conditions can significantly reduce the resilience of the lake ecosystems affecting also their goods and services (Kagalou, 2010).

Our results indicate that $\mathrm{N}$ and $\mathrm{P}$ inflows combined with extremely high water retention time in Lake Karla and Kalamaki Reservoir (Chamoglou et al., 2014) were the main drivers of the phytoplankton succession and dominance. The Nostocales dominance can be linked to the nutrient availability: the DIN/SRP ratio was $<10$ for the most part of the monitoring period, being close to zero in the beginning of the monitoring, which probably triggered the increase of nitrogen-fixing cyanobacteria that dominate under such conditions (Villena and Romo, 2003; Kagalou et al., 2008; Kolzau et al., 2014). The cyanobacteria that formed blooms belong to the functional groups $\mathrm{H} 1, \mathrm{~S} 1$, and $\mathrm{S}_{\mathrm{N}}$ (Reynolds et al., 2002; Mantzouki et al., 2016). L. redekei, P. agardhii, and C. raciborskii (S1 and $\mathrm{S}_{\mathrm{N}}$ species) are particularly tolerant in low irradiance (Mischke and Nixdorf, 2003) and this could account for their dominance in the turbid environment and during the cold period. C. raciborskii, particularly, although generally considered to thrive in warm $\left(>25^{\circ} \mathrm{C}\right.$ ) waters (see Dokulil, 2016 and references therein), has been reported to grow at $17^{\circ} \mathrm{C}$ in German waters (Mischke, 2003) and recently Dokulil (2016) showed its ability to survive in the vegetative form at water temperatures below $12^{\circ} \mathrm{C}$. Its presence in Lake Kalamaki in temperatures as low as $12^{\circ} \mathrm{C}$ may be further evidence of the wide tolerance spectrum of $C$. raciborskii, which enables it to survive and thrive in novel environments (Rzymski and Poniedziałek,

Tab. 4. Cyanotoxin occurrence and concentration (intracellular) in water samples collected from Lake Karla (KL1, KL3) and Kalamaki Reservoir (KK) as determined by LC-MS/MS analysis.

\begin{tabular}{|c|c|c|c|c|c|c|c|c|c|}
\hline \multirow{2}{*}{$\begin{array}{l}\text { Collection } \\
\text { date }\end{array}$} & \multirow{2}{*}{$\begin{array}{l}\text { Sampling } \\
\text { station }\end{array}$} & \multicolumn{8}{|c|}{ Toxin concentration $\left(\mu \mathrm{g} \mathrm{L}^{-1}\right)$} \\
\hline & & $\mathbf{C Y N}$ & ATX-a & STX & Neo-STX & $\begin{array}{l}{\left[\mathrm{D}-\mathrm{Asp}^{3}\right]} \\
\text { MC-RR }\end{array}$ & MC-RR & MC-YR & MC-LR \\
\hline $26-07-13$ & $\begin{array}{l}\text { KL1 } \\
\text { KK } \\
\text { KL3 }\end{array}$ & $\begin{array}{l}2.6 \\
10.1 \\
\text { n.d. }\end{array}$ & $\begin{array}{l}0.8 \\
5.4 \\
\text { n.d. }\end{array}$ & $\begin{array}{l}<\mathrm{LOQ} \\
<\mathrm{LOQ} \\
<\mathrm{LOQ}\end{array}$ & $\begin{array}{l}<\mathrm{LOQ} \\
\text { n.d. } \\
<\mathrm{LOQ}\end{array}$ & $\begin{array}{l}\text { n.d. } \\
\text { n.d. } \\
<\text { LOQ }\end{array}$ & $\begin{array}{c}<\mathrm{LOQ} \\
<\mathrm{LOQ} \\
\text { n.d. }\end{array}$ & $\begin{array}{l}\text { n.d. } \\
\text { n.d. } \\
<\text { LOQ }\end{array}$ & $\begin{array}{l}<\text { LOQ } \\
<\text { LOQ } \\
<\text { LOQ }\end{array}$ \\
\hline $11-09-13$ & $\begin{array}{l}\text { KL1 } \\
\text { KL3 } \\
\text { KK }\end{array}$ & $\begin{array}{l}\text { n.d. } \\
\text { n.d. } \\
0.5\end{array}$ & $\begin{array}{l}\text { n.d. } \\
\text { n.d. } \\
\text { n.d. }\end{array}$ & $\begin{array}{l}<\mathrm{LOQ} \\
<\mathrm{LOQ} \\
<\mathrm{LOQ}\end{array}$ & $\begin{aligned} & \text { n.d. } \\
< & \text { LOQ } \\
< & \text { LOQ }\end{aligned}$ & $\begin{array}{l}\text { n.d. } \\
\text { n.d. } \\
\text { n.d. }\end{array}$ & $\begin{array}{l}\text { n.d. } \\
\text { n.d. } \\
\text { n.d. }\end{array}$ & $\begin{array}{l}<\mathrm{LOQ} \\
\text { n.d. } \\
\text { n.d. }\end{array}$ & $\begin{array}{c}\text { n.d. } \\
\text { n.d. } \\
<\text { LOQ }\end{array}$ \\
\hline $22-11-13$ & $\begin{array}{l}\text { KL1 } \\
\text { KK }\end{array}$ & $\begin{array}{l}\text { n.d. } \\
1.0\end{array}$ & $\begin{array}{l}\text { n.d. } \\
\text { n.d. }\end{array}$ & $\begin{array}{l}<\mathrm{LOQ} \\
<\mathrm{LOQ}\end{array}$ & $\begin{array}{l}<\mathrm{LOQ} \\
\text { n.d. }\end{array}$ & $\begin{array}{l}\text { n.d. } \\
\text { n.d. }\end{array}$ & $\begin{array}{l}\text { n.d. } \\
\text { n.d. }\end{array}$ & $\begin{array}{c}\text { n.d. } \\
<\text { LOQ }\end{array}$ & $\begin{array}{c}\text { n.d. } \\
<\text { LOQ }\end{array}$ \\
\hline $21-02-14$ & KL3 & n.d. & n.d. & $<\mathrm{LOQ}$ & $<\mathrm{LOQ}$ & n.d. & n.d. & n.d. & n.d. \\
\hline 04-07-14 & $\begin{array}{l}\text { KL1 } \\
\text { KK }\end{array}$ & $\begin{array}{c}12.1 \\
<\text { LOQ }\end{array}$ & $\begin{array}{l}2.2 \\
\text { n.d. }\end{array}$ & $\begin{array}{l}<\mathrm{LOQ} \\
<\mathrm{LOQ}\end{array}$ & $\begin{array}{c}\text { n.d. } \\
<\text { LOQ }\end{array}$ & $\begin{array}{l}\text { n.d. } \\
\text { n.d. }\end{array}$ & $\begin{array}{c}<\text { LOQ } \\
\text { n.d. }\end{array}$ & $\begin{array}{l}\text { n.d. } \\
\text { n.d. }\end{array}$ & $\begin{array}{c}<\mathrm{LOQ} \\
\text { n.d. }\end{array}$ \\
\hline 04-09-14 & KK & $<\mathrm{LOQ}$ & n.d. & $<\mathrm{LOQ}$ & n.d. & n.d. & n.d. & n.d. & n.d. \\
\hline 07-11-14 & KL1 & n.d. & n.d. & $<\mathrm{LOQ}$ & n.d. & n.d. & n.d. & n.d. & n.d. \\
\hline
\end{tabular}

LOQ, limit of quantification; n.d., not detected. 
2014). Furthermore, $S 1$ and $S_{N}$ species are only sensitive to flushing (Mantzouki et al., 2016), which never occurred during the monitoring period or earlier (Chamoglou et al., 2014). In shallow Mediterranean lakes, cyanobacterial blooms and their long persistence are more expected at low flushing rates (Romo et al., 2004). A. elenkinii and Sph. aphanizomenoides (H1 species) are only sensitive to low light, low phosphorus and mixing (Reynolds et al., 2002; Mantzouki et al., 2016), conditions rarely met in Lake Karla and Kalamaki Reservoir, enabling them to dominate phytoplankton. L. redekei, P. agardhii A. elenkinii and Sph. aphanizomenoides were found dominant also during previous short-term studies (Papadimitriou et al., 2013; Gkelis and Zaoutsos, 2014). Microcystis species, usually forming blooms in freshwater of Greece (Gkelis et al., 2005, 2014, 2015), also present in Lake Karla's phytoplankton, never dominated a bloom during the mon- itoring period, although such blooms have been reported previously (Gkelis and Zaoutsos, 2014). The high salinity in Lake Karla could also have affected Microcystis and/or other species as it is known that has a negative impact on the diversity of different biota (Padisák et al., 2006). Since Microcystis species are favoured by high irradiance, high temperatures, and they are tolerant to dark anoxic conditions (Šejnohová and Maršálek, 2012), being sensitive only to flushing (Reynolds et al., 2002) or mixing (Visser et al., 2016), it possible that Microcystis-dominated blooms will occur in the future in Lake Karla. Apart from phytoplankton, only four and three benthic macroinvertebrate taxa were recorded in Lake Karla and in Kalamaki Reservoir, respectively, compared to the 12 taxa which had been recorded in the-sole macroinvertebrates' study existing- by Ananiadis (1956), showing a serious deterioration of the water quality. A comparison of the benthic
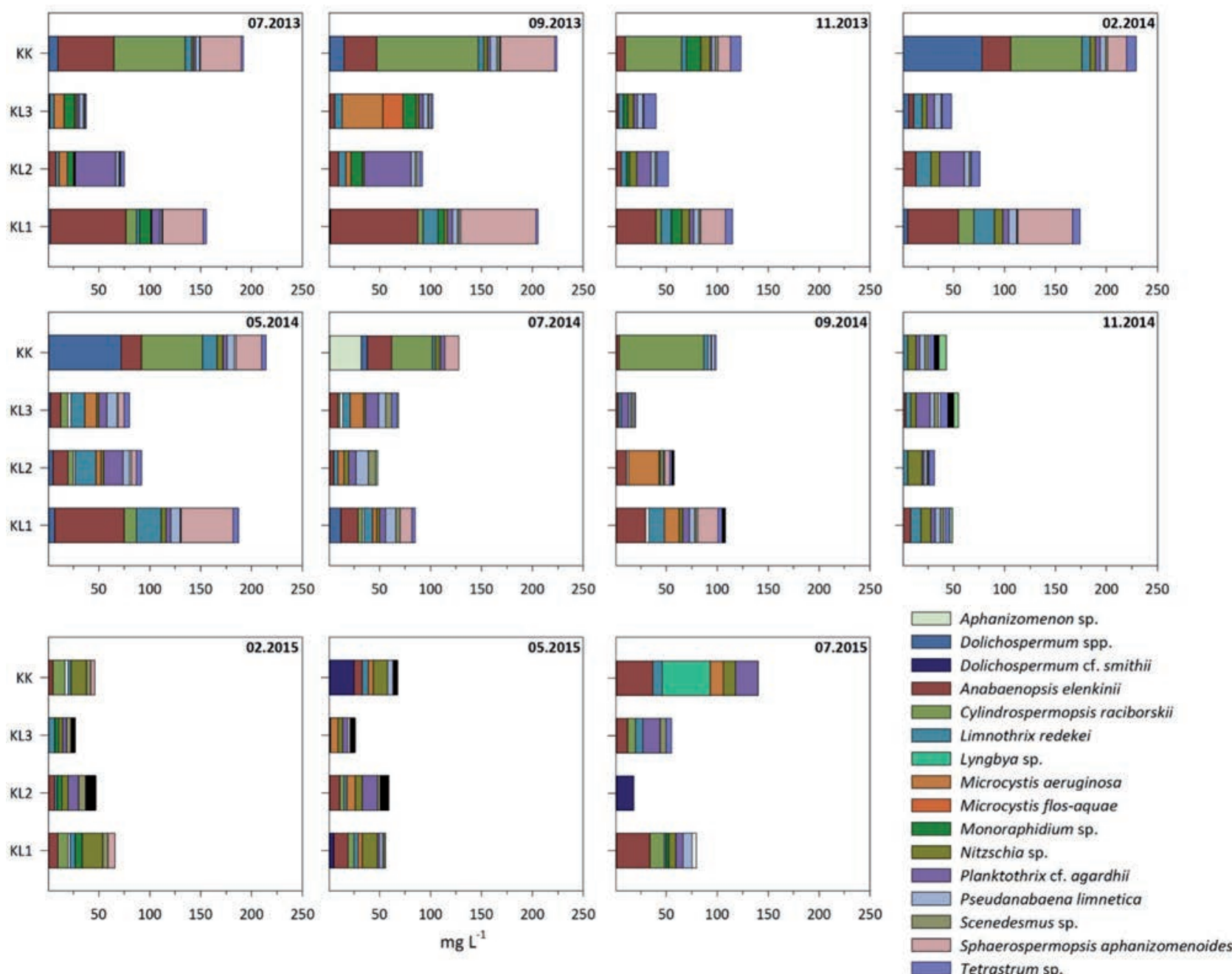

Fig. 6. Biomass of each phytoplankton taxon per sampling period in water samples collected from Lake Karla and Kalamaki Reservoir between July 2013 and July 2015 . Only taxa contributing $>2 \%$ to the total biomass are shown. 
macroinvertebrate diversity with Lake Paralimni, another shallow lake that dried up several times because of the drought (Lakes Network, 2016), using the ShannonWiener index (Shw) showed that Lake Paralimni (Shw $=$ 1.59) has higher biodiversity than Lake Karla $(\mathrm{Shw}=$ $0.73)$ and Kalamaki Reservoir $(\mathrm{Shw}=1.25)$ (Ntislidou, unpuplished data).

Concerning the cyanotoxin production, the main finding of our study was the occurrence of multiple cyanotoxins in several samples of Lake Karla and Kalamaki reservoir. It is known that multiple types of cyanotoxins can be produced by individual cyanobacterial strains and can co-occur in environmental populations, e.g. MCs plus ATX-a, MCs plus ATX-a(S), and nodularin plus MCs (see Codd et al., 2005). Co-occurrence of MCs and CYNs has been found in France (Brient et al., 2009) whereas co-occurrence of MCs and STXs in Brazil (Costa et al., 2006). In Lake Karla, however, we found that MCs, STX, neoSTX, and ATX-a can co-occur, and to the best of our knowledge, this has been reported only once in freshwaters from the Midwestern United States (Graham et al., 2010). The CYN concentrations we found here are within the
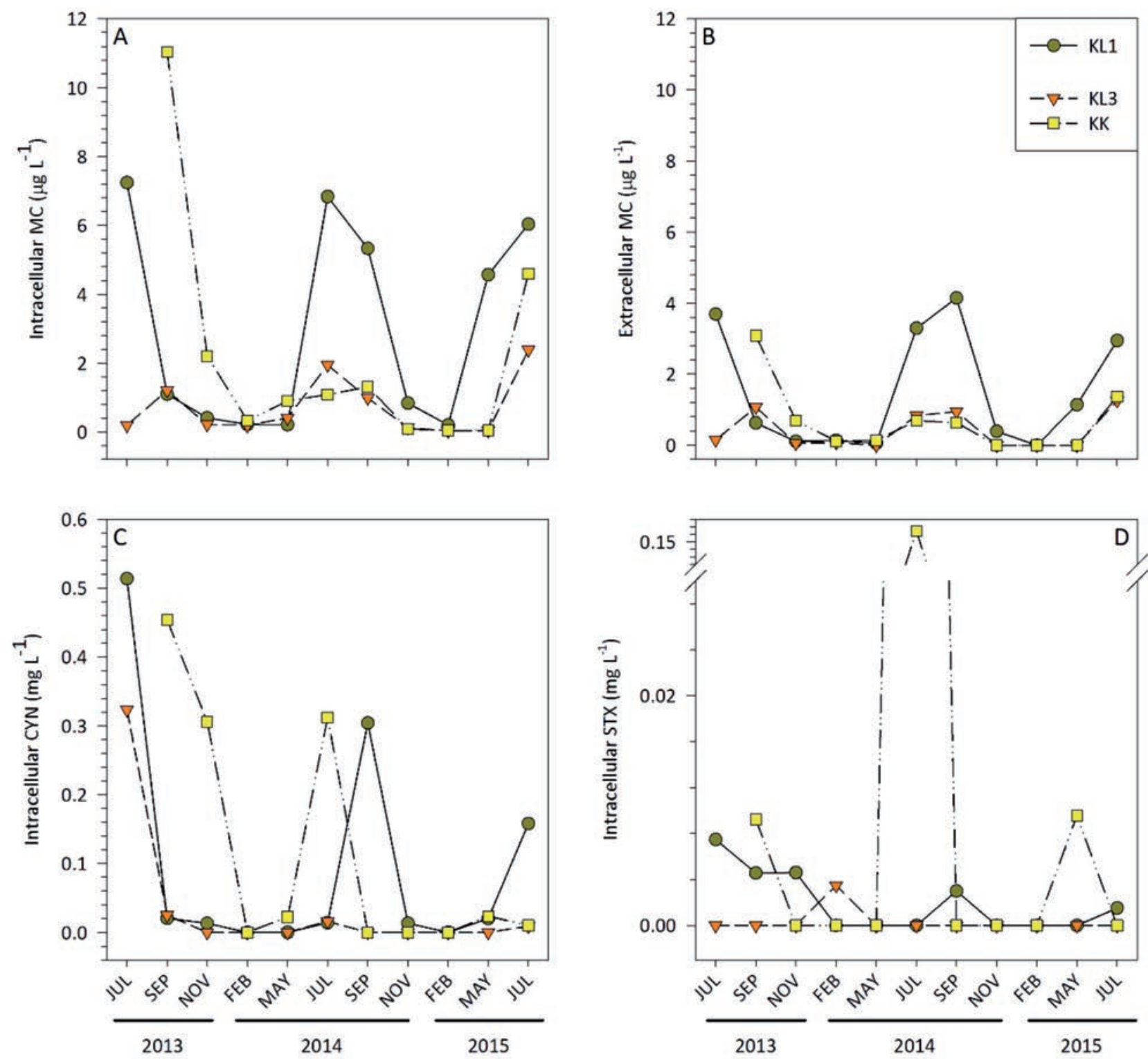

Fig. 7. Cyanotoxin concentrations detected by ELISA in water samples collected from Lake Karla and Kalamaki Reservoir between July 2013 and July 2015. A) Intracellular MCs; B) extracellular MCs; C) CYN; D) STX. 
range obtained in previous studies (Brient et al., 2009; Kokociński et al., 2009; Berry and Lind, 2010), although a value similar to the maximum concentration detected in Lake Karla has only been reported in Germany (Rücker et al., 2007) as dissolved CYN. Studies suggest that CYN is dominantly extracellular (Bormans et al., 2014) therefore the intracelullar concentrations found here may be an underestimation of the total CYN present in the lakes. STXs, generally reported to occur more rarely in freshwaters, have been found in several countries (Testai et al., 2016). STX concentrations in Lake Karla are similar to those reported by Clemente et al. (2010) and previously found in the lake (Gkelis and Zaoutsos, 2014), however the neoSTX/ STX frequency (100\% of the samples analysed by LC-MS/MS) is one of the highest ever reported. ATX-a occurrence was reported for the first time in a Greek freshwater in a previous study by Dimitrakopoulos et al. (2010) although it did not specifically report which freshwaters were sampled. The ATX-a concentrations we found here are similar to those recently reported by Toporowska $\mathrm{et} \mathrm{al}$. (2016). MC concentrations during the monitoring period were in the range reported previously (Papadimitriou et al., 2013), much lower than the ones found at off-shore stations (Gkelis and Zaoutsos, 2014).

In our study CYN and STX was detected in blooms consisting of mixed populations of A. elenkinii, Sph. aphanizomenoides, and C. raciborskii, in line with our previous findings in Lake Karla (Gkelis and Zaoutsos, 2014). Recently it was shown that Aphanizomenon seems to be the main cyanobacterial genus responsible for the production of CYN in Polish lakes (Mankiewicz-Boczek et al., 2012). Evidences point to Aph. gracile as the STX producer in Europe (Ballot et al., 2010; Cirés et al., 2014). Gkelis and Zaoutsos (2014) suggested that $C$. raciborskii and Aphanizomenon (Aph. cf. flos-aquae) could be the possible STX producers in Greece. ATX-a has been found in Dolichospermum (Anabaena) and Aphanizomenon populations worldwide (Testai et al., 2016). The suspected CYN or ATX-a production of Aph. flos-aquae or MC production of Sph. aphanizomenoides is still uncertain (Cirés and Ballot, 2016). Further studies involving strains and/or cyanotoxins gene sequences are needed to identify the cyanotoxins in Lake Karla and Kalamaki Reservoir, as in all cases mixed cyanobacteria populations co-occurred with a mixture of cyanotoxins.

It has been well documented that environmental factors such as temperature, $\mathrm{pH}$, dissolved oxygen, and nutrient availability play an important role in regulating the structure and distribution of phytoplankton communities in lakes (Dolman et al., 2012; Paerl and Paul, 2012), whereas, their influence on cyanotoxin production is more complex (Boopathi and Ki, 2014). Our results indicated that the intracellular MC and CYN concentration was linked to water temperature and SRP concentrations. The positive corre- lation of MCs to temperature, and SRP, found also recently in Lake Pamvotis (Gkelis et al., 2014) can be explained by the fact that in high concentrations of phosphorus $\left(\mathrm{O}^{\prime}\right.$ Neil et al., 2012), or nitrogen or joint nitrogen-phosphorus (Dolman et al., 2012) hepatotoxic strains produce more MCs. However, given the very high level of SRP throughout the study we cannot conclude that SRP has been a determining factor. To date, very few studies have investigated the relationship between CYN concentration and environmental factors potentially affecting its production. Experimental studies were focused, e.g., on effects of temperature (Saker and Griffiths, 2000), nitrogen (Saker and Neilan, 2001), or light (Dyble et al., 2006; Bormans et al., 2014). Our work showed a positive correlation of CYN to temperature in line with Kokociński et al. (2013); earlier experimental studies by Saker and Griffiths (2000) and Preußel et al. (2009) found a reduction of CYN production at temperatures over $20^{\circ} \mathrm{C}$ and $25^{\circ} \mathrm{C}$, respectively. These somewhat contrasting results could be due to the different CYN producers examined and different regulatory mechanisms of CYN-producing strains involved as Wiedner et al. (2008) point out.

In the present study, the phytoplankton biomass (dominated by cyanobacteria) and the MCs concentrations were well above the WHO Guidance Level 2 (WHO, 2003) for recreational waters, posing a moderate health risk throughout the year. In some cases (warm period in Lake Karla and February 2013 in Kalamaki Reservoir), biomass values exceeded also the Guidance Level 3, without, however, the MCs concentration being equally high. Nevertheless, given the co-occurrence of multiple cyanotoxins in Lake Karla, documented in our study, and the fish mortalities (Oikonomou et al., 2012) and MCs accumulation in fish (Papadimitriou et al., 2013) it should be considered that Guidance Level 3 health risks (WHO, 2003) are possible. Therefore, the recommended actions (WHO, 2003), including possible prohibition of watercontact activities, public health follow-up investigation, and informing of the relevant authorities, should be taken. It should be noted that the frequency of recurrent waterbloom phenomena, especially during the warm period, could be much higher than the sampling of this monitoring program, thus a quick and efficient water-bloom early warning system should be implemented.

An overall assessment of the monitoring in Lake Karla and Kalamaki Reservoir indicates that, as in other Greek lakes (Latinopoulos et al., 2016), multiple stressors act synergistically in degrading their ecological status. While the diffuse pollution from agriculture is the single most important source of pollution in most European lakes nowadays, Greek lakes still face point pollution, particularly by nutrients (Latinopoulos et al., 2016). In Lake Karla, nutrient load combining both diffuse and point pollution is $8200 \mathrm{~kg} \mathrm{day}^{-1}$ for $\mathrm{N}$ and $870 \mathrm{~kg}$ day $^{-1}$ for $\mathrm{P}$, re- 
spectively (EGY, 2013). Thus, a drastic reduction of nutrient load should be achieved 'at source level' and before entering the riparian zone. Controlling nutrients remains the basis for managing blooms, no matter which phytoplankton functional type dominates (Mantzouki et al., 2016), therefore the decrease of fertilizer level and the control of the point pollution sources are considered as the only feasible measures. Furthermore, in Lake Karla the continuous water level decline from the suggested 'lower ecological water level' (i.e., $46.4 \mathrm{~m}$ asl) causes accumulation of nutrients which is strengthening the eutrophication. We have not evidence yet about the extent of the nutrient's re-suspension effect through the sediment but it is likely to happen (Scheffer, 2004; Christophoridis et. al, 2006) since the bottom experienced a long fertilization period during the dryness time.

According to the present nutrient and phytoplankton biomass levels, it becomes clear that Lake Karla is a eutrophic system, with apparent signals of hypertrophication during the warm period (Chamoglou et al., 2014; Theologou et al., 2016). The absence of any outlet, and thus of any flushing process, leads to a high-water residence time, strengthening the eutrophic conditions. In shallow Mediterranean lakes, nutrient inputs from the catchment occur mainly in winter-spring due to high precipitation, whereas when there is no outflow, they act as 'nutrient sinks' (Chamoglou et al., 2014). The reduction of the residence time by regulating the annual timing of the inflows and outflows could certainly aim at the improvement of water quality in Lake Karla. This is considered as an emergent issue concerning the future management process.

\section{CONCLUSIONS}

The ecological potential of Lake Karla and Kalamaki Reservoir was less than good based on the biological qualitative elements (benthic macroinvertebrates and mainly phytoplankton) and the co-occurrence of multiple cyanotoxins, implying an intense deterioration of the lake water quality. Our first observations for this deterioration, subject to further investigation, point to: i) the quality of water inflowing from the ditches to both systems, connected to Pinios River; ii) the quantitative management of the lake water (i.e., the irrigation/drainage system of Karla's basin via complex networks and interaction with fields under intensive agriculture); and iii) perhaps the absence of management of the reed bed in the littoral zone of the lake.

The new lake is in the first stage of water filling and its wetland systems are not yet fully functional in order to act as an artificial outflow and reduce incoming organic load by abducting part of the lake's water through the irrigation network. A permanent quality and quantity monitoring system to ensure immediate intervention when incoming pollution loads are large will help habitat protection in Lake Karla and Kalamaki Reservoir. According to the National management plan (EGY, 2013), the completion of works rendering the hydraulic balance of Karla and the rationalisation in the consumption of irrigatory water would help the improvement of the water quality and further the ecological status.

\section{ACKNOWLEDGMENTS}

This study was partially funded by the research program 'Monitoring of Water Quality Parameters' funded by the Management Body of Ecodevelopment Area of Karla, Mavrovouni, Kefalovriso, Velestino, Stefanovikio (Aristotle University of Thessaloniki Research Committee contract No 89623) and managed by Omikron Ltd. The authors gratefully acknowledge CYANOCOST-COST ES 1105 for sharing of knowledge and networking. Disclaimer (T. Kaloudis): The views expressed in this manuscript do not necessarily reflect the views of EYDAP SA.

Author contribution: SG, ML, IK, conceived and designed the study; SG, IC, MP, collected the samples; IC, performed the nutrients' analyses; SG, MP, performed the phytoplankton, molecular, and ELISA analyses; $\mathrm{CN}$, performed the benthic invertebrates' analysis; S-KZ, CC, KM, TMT, TK, AH, performed the LC-MS/MS analyses; SG, MP, visualized the data; SG manuscript drafting. All authors contributed in editing and/or reviewing the manuscript.

\section{References}

Ananiadis CI, 1956. Limnological study of Lake Karla. B. Inst. Ocean. 1083:1-19.

Armitage PD, Hogger J, 1994. Invertebrates ecology and methods of survey, p. 85-97, 151-159. In: N. Holmes, D. Ward and P. Jose, The New Rivers and Wildlife Handbook. RSPB Sandy Bedfordshire UK: 426 pp.

Atashpaz S, Khani S, Barzegari A, Barar J, Vahed SZ, Azarbaijani R, Omidi Y, 2010. A robust universal method for extraction of genomic DNA from bacterial species. Microbiology 79:538-542.

Ballot A, Fastner J, Wiedner C, 2010. Paralytic shellfish poisoning toxin-producing cyanobacterium Aphanizomenon gracile in northeast Germany. Appl. Environ. Microbiol. 76:1173-1180.

Bartram J, Burch M, Falconer IR, Jones G, Kuiper-Goodman T, 1999. Situation assessment, planning and management, pp. 179-209. In: I. Chorus and J. Bartram (eds.), Toxic cyanobacteria in water. 1st ed. World Health Organization, E. \& F.N. Spon.

Beklioglu M, Romo S, Kagalou I, Quintana X, Becares E, 2007. State of the art in the functioning of shallow Mediterranean lakes: workshop conclusions. Hydrobiologia 584:317-26. 
Berry JP, Lind O, 2010. First evidence of "paralytic shellfish toxins" and cylindrospermopsin in a Mexican freshwater system, Lago Catemaco, and apparent bioaccumulation of the toxins in "tegogolo" snails (Pomacea patula catemacensis). Toxicon 55:930-938.

Boopathi T, Ki J-S, 2014. Impact of environmental factors on the regulation of cyanotoxin production. Toxins 6:1951-1978.

Bormans M, Lengronne M, Brient L, Duval C, 2014. Cylindrospermopsin accumulation and release by the benthic cyanobacterium Oscillatoria sp. PCC 6506 under different light conditions and growth phases. Bull. Environ. Contam. Toxicol. 92:243-247.

Brient L, Lengronne M, Bormans M, Fastner J, 2009. First occurrence of cylindrospermopsin in freshwater in France. Environ. Toxicol. 24:415-420.

Chamoglou M, Papadimitriou T, Kagalou I, 2014. Keys-descriptors for the functioning of a Mediterranean reservoir: The case of a new Lake Karla-Greece. Environ. Process. 1:127-135.

Christophoridis C, Fytianos K 2006. Conditions affecting the release of phosphorus from surface lake sediments. J. Environ. Qual. 35:1181-1192.

Cirés S, Ballot A, 2016. A review of the phylogeny, ecology and toxin production of bloom-forming Aphanizomenon spp. and related species within the Nostocales (cyanobacteria). Harmful Algae 54:21-43-

Cirés S, Wörmer L, Ballot A, Agha R, Wiedner C, Velázquez D, Casero MC, Quesada A, 2014. Phylogeography of cylindrospermopsin and paralytic shellfish toxin-producing Nostocales cyanobacteria from Mediterranean Europe (Spain). Appl. Environ. Microbiol. 80:1359-1370.

Codd GA, Lindsay J, Young FM, Morrison LF, Metcalf JS, 2005. Harmful cyanobacteria: from mass mortalities to management measures, p. 1-23. In: J. Huisman, H.C.P. Matthijs, P.M. Visser (eds.), Harmful cyanobacteria. Springer, Dordrecht.

Cook CM, Vardaka E, Lanaras T, 2004. Toxic cyanobacteria in Greek freshwaters, 1987-2000: occurrence, toxicity, and impacts in the Mediterranean region. Acta Hydroch. Hydrob. 32:107-124.

Cooke GD, Welch EG, Peterson SA, Newroth PR, 1986. Limnology, lake diagnosis and selection of restoration methods, p. 9-46. In: G.D. Cooke, E.G. Welch, S.A. Peterson and P.R. Newroth (eds.), Lake and reservoir restoration. Butterworth Publ., Stoneham.

Costa IAS, Azevedo SMFO, Senna PAC, Bernardo RR, Costa SM, Chellappa NT, 2006. Occurrence of toxin-producing cyanobacteria blooms in a Brazilian semiarid reservoir. Braz. J. Biol. 66:211-219.

Dimitrakopoulos I, Kaloudis T, Hiskia A, Thomaidis NS, Koupparis MA, 2010. Development of a fast and selective method for the sensitive determination of anatoxin-a in lake waters using liquid chromatography-tandem mass spectrometry and phenylalanine-d 5 as internal standard. Anal. Bioanal. Chem. 397:2245-2252.

Dokulil MT, Teubner K, 2000. Cyanobacterial dominance in lakes. Hydrobiologia 438:1-12.

Dokulil MT, 2016. Vegetative survival of Cylindrospermopsis raciborskii (Cyanobacteria) at low temperature and low light. Hydrobiologia 764:241-247.

Dolman AM, Rücker J, Pick FR, Fastner J, Rohrlack T, Mischke U, Wiedner C, 2012. Cyanobacteria and cyanotoxins: the in- fluence of nitrogen and phosphorus. PLoS One 7:e38757. Dyble J, Tester PA, Litaker RW, 2006. Effects of light on cylindrospermopsin production in the cyanobacterial HAB species Cylindrospermopsis raciborskii. Afr. J. Mar. Sci. 28:309-312.

EGY, 2013. [River Basin Management Plan of Thessaly].[Report in Greek]. Accessed on: 01/05/2017. Available from: http:// wfd.ypeka.gr/pdf/GR08_Sxedio_diaxeirisis\%20neron_ ypogegrammeno.pdf

EN 27828-1994. Water quality; Methods of biological sampling; Guidance on handnet sampling of aquatic benthic macro-invertebrates (ISO 7828, 1985).

Fergusson KM, Saint CP, 2003. Multiplex PCR assay for Cylindrospermopsis raciborskii and cylindrospermopsin-producing cyanobacteria. Environ. Toxicol. 18:120-125.

Gkelis S, Harjunpää V, Lanaras T, Sivonen K, 2005. Diversity of hepatotoxic microcystins and bioactive anabaenopeptins in cyanobacterial blooms from Greek freshwaters. Environ. Toxicol. 20:249-256.

Gkelis S, Lanaras T, Sivonen K, 2015. cyanobacterial toxic and bioactive peptides in freshwater bodies of Greece: Concentrations, occurrence patterns, and implications for human health. Mar. Drugs 13:6319-6335.

Gkelis S, Papadimitriou T, Zaoutsos N, Leonardos I, 2014. Anthropogenic and climate-induced change favors toxic cyanobacteria blooms: Evidence from monitoring a highly eutrophic, urban Mediterranean lake. Harmful Algae 39:322-333.

Gkelis S, Zaoutsos N, 2014. Cyanotoxin occurrence and potentially toxin producing cyanobacteria in freshwaters of Greece: A multi-disciplinary approach. Toxicon 78:1-9.

Graham J, Loftin K, Meyer M, Ziegler A, 2010. Cyanotoxin mixtures and taste-and-odor-compounds in cyanobacterial blooms from the midwestern United States. Environ. Scien. Technol. 44:7361-7368.

Hisbergues M, Christiansen G, Rouhiainen L, Sivonen K, Borner T, 2003. PCR-based identification of microcystinproducing genotypes of different cyanobacterial genera. Arch. Microbiol. 180:402-410.

ISO 7828, 1985. Water quality - Methods of biological sampling - Guidance on handnet sampling of aquatic benthic macroinvertebrates. International Organization for Standardization.

Jeppesen E, Søndergaard M, Meerhoff M, Lauridsen TL, Jensen JP, 2007. Shallow lake restoration by nutrient loading reduction - some recent findings and challenges ahead. Hydrobiologia 584:239-252.

JRC European Commission, 2009. Water Framework Directive Intercalibration technical report. Part 2: Lakes. Joint Research Centre, European Commission.

Jungblut AD, Neilan BA, 2006. Molecular identification and evolution of the cyclic peptide hepatotoxins, microcystin and nodularin, synthetase genes in three orders of cyanobacteria. Arch. Microb. 185:107-114.

Kagalou I, 2010. Classification and management issues of Greek lakes under the European Water Framework Directive: a DPSIR approach. J. Environ. Monitor. 12:2207-2215.

Kagalou I, Papastergiadou E, Leonardos I, 2008. Long term changes in the eutrophication process in a shallow Mediterranean lake ecosystem of W. Greece. Response after the reduction of external load. J. Environ. Manag. 87:497-506.

Kellmann R, Mihali TK, Jeon YJ, Pickford R, Pomati F, Neilan 
BA, 2008. Biosynthetic intermediate analysis and functional homology reveal a saxitoxin gene cluster in cyanobacteria. Appl. Environ. Microb. 74:4044-4053.

Kokociński M, Dziga D, Spoof L, Stefaniak K, Jurczak T, Mankiewicz- Boczek J, Meriluoto J, 2009. First report of the cyanobacterial toxin cylindrospermopsin in the shallow, eutrophic lakes of western Poland. Chemosphere 74:669-675.

Kokociński M, Mankiewicz- Boczek J, Jurczak T, Spoof L, Meriluoto J, Rejmonczyk E, Hautala H, Vehniäinen M, Pawełczyk J, Soininen J, 2013. Aphanizomenon gracile (Nostocales), a cylindrospermopsin producing cyanobacterium in Polish lakes. Environ. Sci. Pollut. Res. 20:52435264.

Kolzau S, Wiedner C, Rücker J, Köhler J, Köhler A, Dolman AM, 2014. Seasonal patterns of nitrogen and phosphorus limitation in four German lakes and the predictability of limitation status from ambient nutrient concentrations. PloS One 9:e96065.

Komárek J, 2013. [Cyanoprokaryota 3. Teil: Heterocytous genera]. In: B. Büdel, G. Gärtner, L. Krienitz and M. Schagerl (eds.), [Süswasserflora von Mitteleuropa, Freshwater flora of Central Europe].[Book in German]. Springer Spektrum Berlin: 1130 pp.

Komárek J, Anagnostidis K, 1999.[ Cyanoprokaryota 1. Teil: Chroococcales]. In: H. Ettl, G. Gärtner, H. Heynig, and D. Mollenhauer (eds.), [Süsswasserflora von Mitteleuropa 19/1].[Book in German]. Gustav Fischer Verlag, Jena: 548 pp

Komárek J, Anagnostidis K, 2005. [Cyanoprokaryota 2. Teil: Oscillatoriales]. In: H. Ettl, G. Gärtner, H. Heynig, and D. Mollenhauer (eds.), [Süsswasserflora von Mitteleuropa 19/1].[Book in German]. Gustav Fischer Verlag, Jena: 759 pp.

Lakes Network, 2016. Lake Paralimni. Accessed on: 02/24/2017. Available from: http://lakesnetwork.eu/english/lakes/lake-paralimni-2/

Latinopoulos D, Ntislidou C, Kagalou I, 2016. Multipurpose plans for the sustainability of the Greek lakes: emphasis on multiple stressors. Environ. Process. 3:589.

Loukas A, Mylopoulos N, Vasiliades L, 2007. A modelling system for the evaluation of water resources management scenarios in Thessaly, Greece. Water Resour. Manage. 21:1673-702.

Mankiewicz-Boczek J, Kokocinski M, Gagala I, Pawelczyk J, Jurczak T, Dziadek J, 2012. Preliminary molecular identification of cylindrospermopsin-producing cyanobacteria in two Polish lakes (Central Europe). Microbiol. Lett. 326:173-179.

Mantzouki E, Visser PM, Bormans M, Ibelings BW. 2016. Understanding the key ecological traits of cyanobacteria as a basis for their management and control in changing lakes. Aquat. Ecol. 50:333-350.

Mischke U, Nixdorf B, 2003. Equilibrium phase conditions in shallow German lakes: How Cyanoprokaryota species establish a steady state phase in late summer. Hydrobiologia 502:123-132.

Mischke U, 2003. Cyanobacteria associations in shallow polytrophic lakes: influence of environmental factors. Acta Oecologica 24:S11-S23.

Moustaka- Gouni M, Michaloudi E, Sommer U, 2014. Modifying the PEG model for Mediterranean lakes - no biological winter and strong fish predation. Freshwater Biol. 59:11361144.

Moustaka-Gouni M, Hiskia A, Genitsaris S, Katsiapi M, Manolidi
K, Zervou S-K, Christophoridis C, Triantis TM, Kaloudis T, Orfanidis S, 2016. First report of Aphanizomenon favaloroi occurrence in Europe associated with saxitoxins and a massive fish kill in Lake Vistonis, Greece. Mar. Freshwater Res. DOI: http://dx.doi.org/10.1071/MF16029

Nonneman D, Zimba P, 2002. A PCR-based test to assess the potential for microcystin occurrence in channel catfish production ponds. J. Phycol. 38:230-234.

O'Neil JM, Davis TW, Burford MA, Gobler CJ, 2012. The rise of harmful cyanobacteria blooms: the potential roles of eutrophication and climate change. Harmful Algae 14:313-334.

Oikonomou A, Katsiapi M, Karayanni H, Moustaka-Gouni M, Kormas, K, 2012. Plankton microorganisms coinciding with two consecutive mass fish kills in a newly reconstructed lake. Sci. World J. 2012:1-14.

Ouahid Y, Pérez-Silva G, Campo FFD, 2005. Identification of potentially toxic environmental Microcystis by individual and multiple PCR amplification of specific microcystin synthetase gene regions. Environ. Toxicol. 20:235-242.

Padisák J, Borics G, Grigorszky I, Soróczki-Pintér É, 2006. Use of phytoplankton assemblages for monitoring ecological status of lakes within the Water Framework Directive: the assemblage index. Hydrobiologia, 553:1-14.

Paerl HW, 2014. Mitigating harmful cyanobacterial blooms in a human- and climatically-impacted world. Life. 4:988-1012.

Paerl HW, Hall NS, Calandrino ES, 2011. Controlling harmful cyanobacterial blooms in a world experiencing anthropogenic and climatic-induced change. Sci. Total Environ. 409:1739-1745.

Paerl HW, Otten GT, 2013. Harmful cyanobacterial blooms, causes, consequences, and controls. Microb. Ecol. 65:9951010.

Paerl HW, Paul V, 2012. Climate change: links to global expansion of harmful cyanobacteria. Water Res. 46:1349-1363.

Papadimitriou T, Katsiapi M, Kormas KA, Moustaka-Gouni M, Kagalou I, 2013. Artificially-born "killer" lake: Phytoplankton based water quality and microcystin affected fish in a reconstructed lake. Sci. Total Environ. 452-453:116-124.

Preußel K, Wessel G, Fastner J, Chorus I, 2009. Response of cylindrospermopsin production and release in Aphanizomenon flos-aquae (Cyanobacteria) to varying light and temperature conditions. Harmful Algae 8:645-650.

Reynolds CS, Huszar V, Kruk C, Naselli-Flores L, Melo S, 2002. Towards a functional classification of the freshwater phytoplankton. J. Plankton Res. 24:417-428.

Romo S, Miracle MR, Villena MJ, Rueda M, Ferriol C, Vicente E, 2004. Mesocosm experiments on nutrient and fish effects on shallow lake food webs in a Mediterranean climate. Freshwater Biol. 49:1593-607.

Rücker J, Stüken A, Nixdorf B, Fastner J, Chorus I, Wiedner C, 2007. Concentrations of particulate and dissolved cylindrospermopsin in 21 Aphanizomenon-dominated temperate lakes. Toxicon 50:800-809.

Rzymski P, Poniedziałek B, 2014. In search of environmental role of cylindrospermopsin: a review on global distribution and ecology of its producers. Water Research 66:320-337.

Saker ML, Griffiths DJ, 2000. Effects of temperature on growth and cylindrospermopsin content of seven isolates of Cylindrospermopsis raciborskii (Nostocales, Cyanophyceae) from water bodies in northern Australia. Phycologia 39:349-354. 
Saker ML, Neilan BA, 2001. Varied diazotrophies, morphologies and toxicities of genetically similar isolates of Cylindrospermopsis raciborskii (Nostocales, Cyanophyceae) from water bodies in northern Australia. Appl. Environ. Microbiol. 99:749-757.

Scheffer M, 2004. Ecology of shallow lakes. Springer Science+Business Media, Dordrecht: 378 pp.

Schembri MA, Neilan BA, Saint CP, 2001. Identification of genes implicated in toxin production in the cyanobacterium Cylindrospermopsis raciborskii. Environ. Toxicol.16:413-421.

Šejnohová L, Maršálek B, 2012.Microcystis, p. 195-221. In: B.A. Whitton (ed.), Ecology of Cyanobacteria. II. Their diversity in space and time. Springer, Dordrecht.

Sidiropoulos P, Papadimitriou T, Stabouli Z, Loukas A, Mylopoulos N, Kagalou I, 2012. Past, present and future concepts for conservation of the re-constructed Lake Karla (Thessaly-Greece). Fresenius Environ. Bull. 21:3027-34.

Testai E, Scardala S, Vichi S, Buratti FM, Funari E, 2016. Risk to human health associated with the environmental occurrence of cyanobacterial neurotoxic alkaloids anatoxins and saxitoxins. Crit. Rev. Toxicol. 46:385-419.

Theologou I, Kagalou I, Papadopoulou MP, Karantzalos K, 2016. Multitemporal mapping of chlorophyll- $\alpha$ in Lake Karla from high resolution multispectral satellite data. Environ. Process. 3:681.

Timm T, 2009. A guide to the freshwater Oligochaeta and Polychaeta of Northern and Central Europe. Lauterbornia 66: $1-235$.

Toporowska M, Pawlik-Skowrońska B, Kalinowska R, 2016. Mass development of diazotrophic cyanobacteria (nostocales) and production of neurotoxic anatoxin-a in a Plank- tothrix (oscillatoriales) dominated temperate lake. Water Air Soil Pollut. 227:321.

Utermöhl H, 1958. [Zur Vervollkommung der quantitativinen phytoplankton-Methodik].[Article in German]. Int. Ver. Theor. Angew. Limnol. 9:1-38.

Vasconcelos V, Martins A, Vale M, Antunes A, Azevedo J, Welker M, Lopez O, Montejano G, 2010. First report on the occurrence of microcystins in planktonic cyanobacteria from Central Mexico. Toxicon 56:425-431.

Villena MJ, Romo S, 2003. Phytoplankton changes in a shallow Mediterranean lake (Albufera of Valencia, Spain) after sewage diversion. Hydrobiologia. 506:281-287.

Visser PM, Ibelings BW, Bormans M, Huisman J. 2016. Artificial mixing to control cyanobacterial blooms: a review. Aquat. Ecol. 50:423-441.

WHO (World Health Organization), 2003. Guidelines for Safe Recreational Water Environments. 1. Coastal and Fresh Waters. WHO, Geneva.

Wiederholm T, 1983. Chironomidae of the Holarctic region. Keys and diagnoses. Part I. Larvae: Entomol. Scand. Supplement, 1-457.

Wiederholm T, 1986. Chironomidae of the Holarctic region. Keys and diagnoses. Part II. Pupae: Entomol. Scand. Supplement, 1-482.

Wiedner C, Rücker J, Fastner J, Chorus I, Nixdorf B, 2008. Seasonal dynamics of cylindrospermopsin and cyanobacteria in two German Lakes. Toxicon 52:677-786.

Zervou S-K, Christophoridis C, Kaloudis T, Triantis TM, Hiskia A, 2017. New SPE-LC-MS/MS method for simultaneous determination of multi-class cyanobacterial and algal toxins. J. Hazard. Mater. 323:56-66. 